\title{
Lamiaceae Family Plants as a Potential Anticholinesterase Source in the Treatment of Alzheimer's Disease
}

\section{Alzheimer Hastalığı Tedavisinde Potansiyel Antikolinesteraz Bir Kaynak Olarak Lamiaceae Familyası Bitkileri}

Gulacti TOPCU, Tuba KUSMAN

Faculty of Pharmacy, Bezmialem Vakif University, Istanbul, Turkey

\section{ABSTRACT}

Alzheimer's disease (AD) is one of the most common and progressive neurodegenerative disorders with dementia in the world. The precise causes of AD are not fully understood yet, although several important features of its pathophysiology are well described. Current $\mathrm{AD}$ treatment is symptomatic and is mainly, but not exclusively, focused on the inhibition of cholinesterases (ChEs). There are four cholinesterase inhibitors approved by the U.S. Food and Drug Administration (FDA): tacrine, donepezil, rivastigmine, and galantamine. Among them, galantamine is a natural drug, and rivastigmine is a derivative of the natural drug physostigmine. In addition, only an NMDA (N-methyl$\mathrm{D}$-aspartate) receptor antagonist, memantine, is also approved by the FDA in the treatment of patients with moderate to severe AD. However, none of them provides a satisfactory treatment for Alzheimer's disease, and studies are still going on to find new potential drugs from both synthetic chemicals and natural sources.

In this review, studies on the discovery of new cholinesterase inhibitors from natural sources, particularly from Lamiaceae family plants were evaluated, and a number of terpenoids and phenolics/flavonoids isolated are presented as potential drugs in the treatment of Alzheimer's disease.

Key Words: Alzheimer's disease, galantamin, NMDA reseptör antagonist, Lamiaceae, alkaloidler, terpenoidler

\section{ÖZET}

Alzheimer hastalığı (AH) demansla seyreden en yaygın ve gittikçe ilerleyen nörodejeneratif hastalıklardan biridir. Patofizyolojisi ile ilgili önemli özellikleri oldukça iyi belirlenmiş olmasına rağmen hala AH'nın kesin nedenleri tam olarak anlaşılamamıştır. Mevcut AH tedavisi semptomatiktir ve başlıca (fakat yegâne değil) kolinesteraz inhibitörleri üzerine odaklıdır. Amerikan Gıda ve İlaç Dairesi (FDA) tarafından onaylanmış olan dört kolinesteraz inhibitörü takrin, donepezil, galantamin, rivastigmindir ve bunlardan galantamin doğal, rivastigmin ise doğal antikolinesteraz olan fizostigminin bir türevidir. Bunlara ilaveten, bir NMDA (N-metil-D-aspartat) reseptör antagonisti olan memantin ortaileri derecede $\mathrm{AH}$ tedavisi için FDA tarafından onaylanmıştır. Fakat bunlardan hiçbiri tam anlamıyla Alzheimer hastalığını tatmin edici bir tedavi sunamamaktadır. Bu nedenle doğal ve sentetik kaynaklı yeni potansiyel ilaçlar üzerindeki çalışmalar devam etmektedir.

$\mathrm{Bu}$ derlemede yeni kolinesteraz inhibitörlerinin doğal kaynaklardan, özellikle Lamiaceae familyası bitkilerinden keşfedilmesi çalışmaları gözden geçirildi ve izole edilen pek çok terpenik, fenolik/flavonoid bileşik Alzheimer hastalığının tedavisi için potansiyel ilaç olarak sunuldu.

Anahtar Sözcükler: Alzheimer hastalığı, galantamine, NMDA receptor antagonist, Lamiaceae, alkaloids, terpenoids

\section{Introduction}

Alzheimer's disease (AD) is a neurodegenerative disease that primarily affects the elderly population over 65 years of age, is estimated to account for about $70 \%$ of the dementia cases, and now affects approximately 24 million people worldwide (1).

Alzheimer's disease $(\mathrm{AD})$ is named after the German physician Aloes Alzheimer, who first described it in 1906. Alzheimer's disease $(\mathrm{AD})$ is a slowly progressive disease of the brain that is characterized by memory loss, difficulty performing familiar tasks, problems with language, disorientation of time and place, poor or decreased judgment, problems with abstract thinking, misplacing things, changes in mood or behavior, changes in personality, and loss of initiative. 
Accumulation of the protein amyloid plays a significant role in the development of Alzheimer's disease, which is a characteristic hallmark, besides the protein tau angles in the patients with $\mathrm{AD}(2)$. However, Alzheimer's disease is diagnosed when a person has sufficient cognitive decline to meet the criteria for dementia or the clinical course is consistent with that of AD. Many other causes of dementia are screened for, prior to diagnosing Alzheimer's disease, and the period of the disease may extend to 3-10 years (2).

The acetylcholinesterase (AChE) enzyme predominates in a healthy brain, with the butyrylcholinesterase (BChE) enzyme considered to play a minor role in regulating brain acetylcholine (ACh) levels. The exact cause of $\mathrm{AD}$ is not well understood yet. The brains of those with mild-to-moderate Alzheimer's disease, a progressive type of dementia, have abnormally low acetylcholine concentrations. This means that any compound that enhances the cholinergic system in the brain may be useful in treating Alzheimer's disease and similar brain malfunctions. However, $\mathrm{BChE}$ activity progressively increases in patients with $\mathrm{AD}$, while $\mathrm{AChE}$ activity remains unchanged or declines. The two enzymes differ in substrate specificity, kinetics, and activity in different brain regions. Recent evidence suggests that both $\mathrm{AChE}$ and $\mathrm{BChE}$ may have roles in the etiology and progression of $\mathrm{AD}$ beyond regulation of synaptic acetylcholine levels $(2,3)$.

Genetic factors correlate with early-onset $\mathrm{AD}$, consisting of mutations in amyloid precursor protein (APP) and presenilins 1 and 2 (PS1 \& PS2), along with APP gene duplication. However, factors of late-onset or sporadic $\mathrm{AD}$ are not understood enough yet (4), which requires further studies. Prevention of non-genetic $\mathrm{AD}$ can be managed with available drugs, to some degree. Elevated levels of tocopherol and tocotrienol forms are found to be associated with reduced risk of cognitive impairment in the elderly (5). In addition to vitamin E, vitamin C and beta carotene, as well as many natural compounds, may help in scavenging free radicals generated during the initiation and progression of this disease. Several natural substances with neuroprotective effects have been widely studied by a number of researchers. Most of the isolates have remarkable antioxidant properties, mainly by scavenging free radical species. Some of them increase cell survival and improve cognition by directly affecting amyloidogenesis and programmed cell death pathways (6). However, there is still an immediate requirement for both the diagnosis for patients with $\mathrm{AD}$ at the early stage and exploration of more efficient drugs than the ones prescribed by physcians at present, as known cholinesterase inhibitors and NMDA glutamate receptor antagonists can not provide a fully satisfactory cure for Alzheimer's disease. Besides AD, there are a number of neurodegenerative disorders and diseases with dementia, which are classified as senile; vascular; with Lewy bodies; mixed type; and dementia in Parkinson's disease (PD) and Huntington's disease $(7,8)$.

In this review article, natural plants have been evaluated for the treatment of $\mathrm{AD}$, particularly Lamiaceae family plant ex- tracts and their pure compounds, as potential anticholinesterase agents.

\section{Present Treatment of AD}

As it is known, two types of cholinesterases are present in the healthy human body, acetyl- and butyryl-cholinesterases. In the human brain, BChE (in some articles abbreviated as BuChE) predominantly appears to have a neuroglial distribution, whereas $\mathrm{AChE}$ is mainly located within cholinergic axons and the cell bodies of neurons. However, both enzymes are also found in neuritic plaques and tangles in patients with $\mathrm{AD}(9)$.

Butyrylcholine is not a physiological substrate in the human brain, and the only chemical difference from $\mathrm{ACh}$ is the presence of two additional methylene $\left(\mathrm{CH}_{2}\right)$ groups in $\mathrm{BCh}$. Due to its predominantly neuronal distribution, AChE activity is higher than BChE activity in the human brain. Depending on the region, human brain AChE activity is 1.5 -fold (temporal and parietal cortex) to 60-fold (caudate nucleus) higher than BChE activity (10).

The loss of memory is considered to be the result of a shortage of the nerve transmitter acetylcholine. It is possible to increase the level of this transmitter in the brain by inhibiting the activity of the enzyme acetylcholinesterase, which splits or breaks down the transmitter substance. Drugs that inhibit the breakdown of the messenger or transmitter acetylcholine delay the development of the disease (8), which explains the cholinesterase cascade in $\mathrm{AD}$.

In order to find new natural agents for the treatment of $\mathrm{AD}$ based on the cholinesterase inhibitory mechanism, many research groups in the world study different plants from various families, including the Amaryllidaceae, Fumariaceae, Papaveraceae, and Lamiaceae (11) families. So far, some potential triterpenoids (12), such as ursolic acid and oleanolic acid, ginsenosides, gingkolides, and cannabinoids have been studied as potential cholinesterase inhibitors in $\mathrm{AD}$ treatment, but they are still awaiting clinical trials (12), as well as some plants that contain different types of alkaloids $(11,13)$.

Many drugs currently available in western medicine were originally isolated from plants or are derived from templates of compounds isolated from plants. The two major synthetic $\mathrm{AD}$ therapeutics available on the market are tacrine and donepezil as acetylcholinesterase inhibitors, besides a natural drug, galantamine, and a naturally derived compound, rivastigmine (Table 1) (14).

At present, two types of medications in $\mathrm{AD}$ treatment are approved by the FDA; these are cholinesterase inhibitors and a glutamate NMDA receptor antagonist.

\section{Cholinesterase inhibitors}

As cholinesterase inhibitors, donepezil (Aricept), rivastigmine (Exelon), galantamine (Razadyne, Reminyl), and tacrine (Cognex) are on the market, prescribed for early to moderate 
Table 1. FDA Approved four anticholinesterase drugs in AD treatment

\begin{tabular}{|c|c|c|c|c|}
\hline & Tacrine & Rivastigmine & Donepezil & Galanthamine \\
\hline Brand name & Cognex & Exelon, generic & Aricept & Razadyne*, generic \\
\hline Enzymes inhibited & AChE, BChE & AChE, BChE & AChE & AChE \\
\hline Mechanism & Noncompetitive & Noncompetitive & Noncompetitive & Competitive \\
\hline 'Typical maintenance dose & 20 mg four times daily & $\begin{array}{l}9.5 \mathrm{mg} / 24 \mathrm{~h} \text { (transdermal) } \\
3-6 \mathrm{mg} \text { twice daily } \\
\text { (oral) }\end{array}$ & 10 mg once daily & $\begin{array}{c}\text { 8-12 mg twice daily } \\
\text { (immediate release) } \\
16-24 \mathrm{mg} / \text { day } \\
\text { (extended release) }\end{array}$ \\
\hline \multirow[t]{2}{*}{ FDA-approved indications } & Mild-moderate AD ** & Mild-moderate AD & Mild-severe AD & Mild-moderate AD \\
\hline & & Mild-moderate PD & & \\
\hline \multirow[t]{2}{*}{ 'Metabolism } & CYP1A2 & Esterases & CYP2D6 & CYP2D6 \\
\hline & & & CYP3A4 & CYP3A4 \\
\hline \multicolumn{5}{|c|}{ 'Typical starting doses are one-half of the maintenance dose and are given for the first month of therapy } \\
\hline \multicolumn{5}{|c|}{$\begin{array}{l}\text { 'Drugs metabolized by CYP2D6 and CYP3A4 are subject to increased serum levels when co-administered with drugs known to inhibit these enzymes, such } \\
\text { as ketoconazole and paroxetine. Similarly, tacrine levels are increased by co-administration with the CYP1A2 inhibitors theophylline, cimetidine, and fluvox- } \\
\text { amine (It's adopted by Standaert DG,Roberson ED 2010) }\end{array}$} \\
\hline
\end{tabular}

stages to treat symptoms related to memory, thinking, language, judgment, and some other thought processes, aiming to prevent the breakdown of acetylcholine, a chemical messenger that is important for learning and memory. Thus, communications among nerve cells are carried out by keeping acetylcholine levels high. However, a delayed worsening of symptoms may be realized 6 to 12 months or a maximum of 2 years for about half of people with AD.

According to the FDA, of the prescribed drugs, donepezil (Aricept) is approved to treat all stages of $\mathrm{AD}$ and rivastigmine (Exelon) and galantamine (Razadyne, Reminyl) are approved to treat mild to moderate AD. Cholinesterase inhibitors have some side effects, such as nausea, vomiting, loss of appetite, and increased frequency of bowel movements, but are generally tolerated. But, tacrine (Cognex) is now rarely prescribed by physicans because of hepatotoxicity and adverse effects, although it was the first its cholinesterase inhibitor approved by the FDA.

\section{Galantamine}

Several plant species contain alkaloids with cholinesterase inhibitor activity; for example, galantamine was discovered in the bulbs of Galanthus nivalis L. (snowdrop) (Figure 1), known as 'kardelen' in Turkey, which is one of the Amaryllidaceae family plants. Galantamine, with a similar structure to morphine (Figure 2), originally was found in species of Narcissus tazetta L. and Leucojum aestivum $\mathrm{L}$. and Lycoris radiata Herb., belonging to the same family. Selective and competitive inhibition of AChE is considered the principal mode of action of galantamine, although other mechanistic effects have been suggested to contribute to observed cognitive improvements (2).

The tolerability and safety of galantamine in $\mathrm{AD}$ have not been compared with those of the synthetic AChE inhibitor

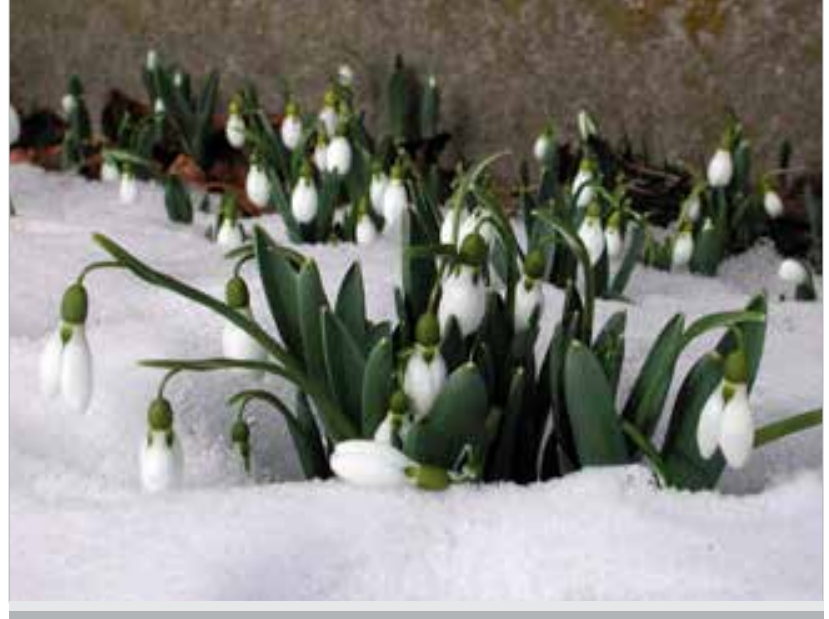

Figure 1. Galanthus nivalis L.

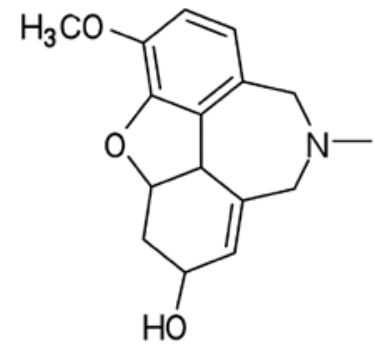

galantamine

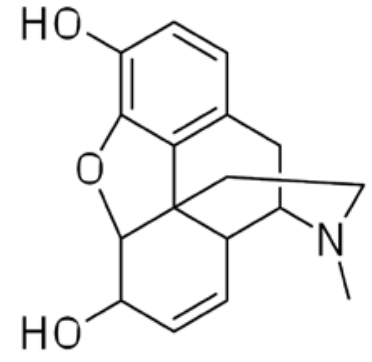

morphine
Figure 2. Structures of galantamine and morphine

donepezil (15). Optimization of the drug delivery and formulation of galantamine has extended investigations into the intranasal route (16) and prodrugs. 
Although numerous synthetic derivatives of galantamine have been developed to obtain more potent and selective AChE inhibitory properties, their clinical potential has yet to be explored. Other Amaryllidaceae alkaloids and synthetic derivatives have been shown to inhibit AChE (17), including ungeremine (Figure 3) from Nerine bowdenii W. Watson, Galanthus, and Narcissus species, which is a more potent AChE inhibitor than galantamine (4). Lycorine (Figure 3) inhibits AChE but is also cytotoxic, which probably limits any clinical potential (17).

\section{Physostigmine and derivatives}

Physostigmine (Figure 4) is a pyrroloindole alkaloid, isolated from the calabar bean (Physostigma venenosum Balf.), having a carbamate moiety that is principally responsible for reversible inhibition of AChE (17). It was presented as the first known AChE inhibitor; however, it inhibited both AChE and BChE<smiles>COCCOc1cc2c(OCO)cc1C1C2N2CCC(=C[C@@H](O)[C@H]1O)C2</smiles>

Figure 3. Structures of ungeremine and lycorine in a smilar submicromolar range $\left(\mathrm{IC}_{50}=0.015\right.$ and $0.016 \mu \mathrm{M}$, respectively) (18).

This alkaloid improved cognitive functions in rats with scopolamine-induced cognitive impairment and in $\mathrm{AD}$ patients (19). However, a Cochrane review concluded later on that the evidence for efficacy of physostigmine on $\mathrm{AD}$ is limited and that adverse effects are common (20).

To improve the pharmacokinetic and therapeutic profiles, synthetic derivatives of physostigmine have been investigated.

One of the physostigmine derivatives, eptastigmine (heptylphysostigmine tartrate) (Figure 4), inhibited both AChE and $\mathrm{BChE}$ and improved cognition in $\mathrm{AD}$, however, its hematological effects halted further study (21).

Other derivatives (Figure 5) of physostigmine including cymserine, bisnorcymserine ( $\mathrm{N}$-demethylated cymserine), and tetrahydrofurobenzofuran cymserine inhibited BChE (22). Another derivative, phenserine, an inhibitor of $\mathrm{AChE}$ and amyloid precursor protein (APP), has lower toxicity than physostigmine (Figure 4), tacrine (23), and rivastigmine (Figure 6). Some other alkaloids, such as steroidal alkaloids and huperzine $\mathrm{A}$, which is a sesquiterpene alkaloid, have also been detected for anticholinesterase properties (1). Huperzine A (Figure 7) has been obtained from Huperzia serrata (Thunb. ex Murray) Trevis and some other Huperzia species (Lycopodiaceae family), used in Indian and Chinese traditional medi-<smiles>CCCCCCCN</smiles>

physostigmine<smiles>CN1CCC2(C)c3cc(OC(N)=O)ccc3N(C)C12</smiles>

eptastigmine

Figure 4. Structures of physostigmine and its derivative eptastigmine

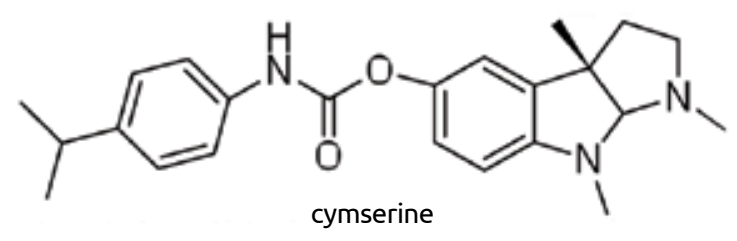<smiles>CC(C)c1ccc(NC(=O)Oc2ccc3c(c2)[C@@]2(C)CCNC2N3)cc1</smiles><smiles>CC(C)c1ccc(NC(=O)Oc2ccc3c(c2)[C@@]2(C)CCOC2O3)cc1</smiles>

tetrahydrofurobenzofuran cymserine<smiles>CN1CC[C@]2(C)c3cc(OC(=O)Nc4ccccc4)ccc3N(C)C12</smiles>

phenserine

Figure 5. Structures of pysostigmine derivatives: cymserine, bisnorcymserine, tetrahydrofurobenzofuran cymserine, phenserine 


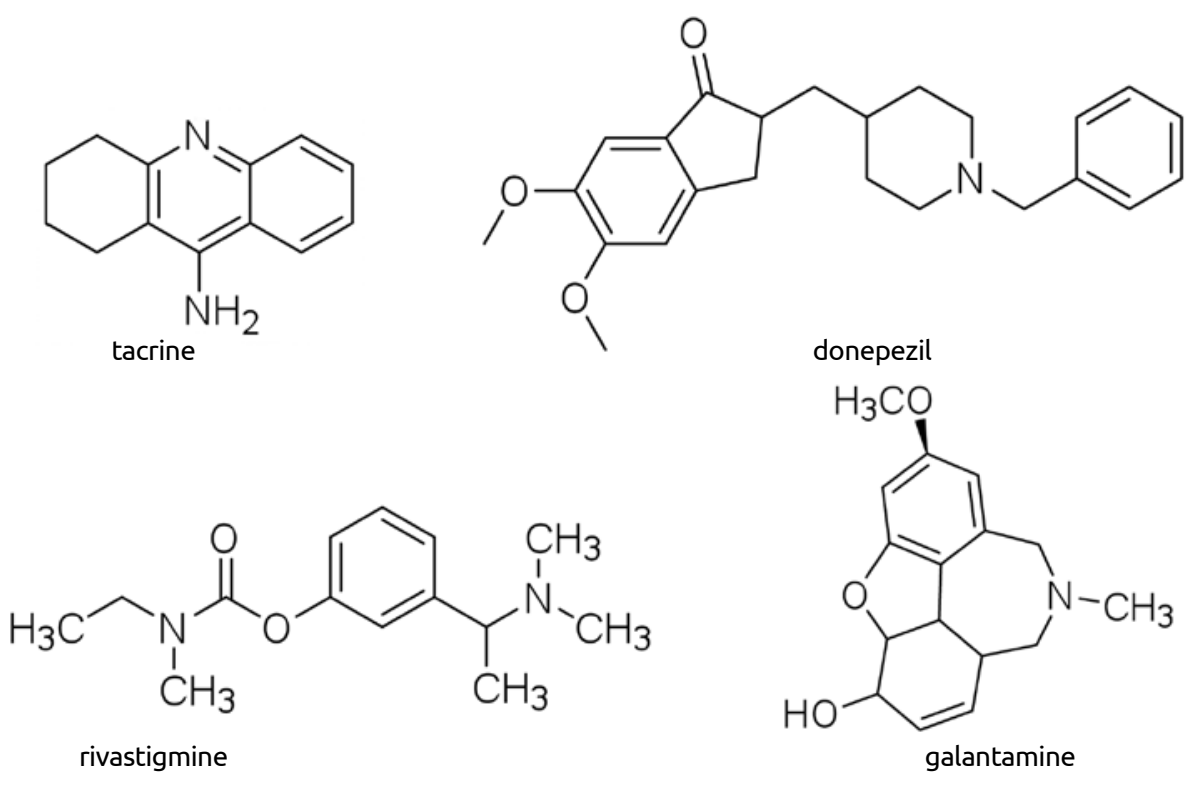

Figure 6. The FDA approved cholinesterase inhibitors

cine and widely distributed over the counter as a nootropic and dietary supplement. It is an AChE inhibitor and NMDA receptor antagonist and now under phase III trial stage studies to become a drug in the treatment of AD.

\section{$\mathrm{N}$-methyl-D-aspartate (NMDA) glutamate receptor antagonist}

Memantine (an NMDA glutamate receptor antagonist) (trade name Namenda, or Ebixa) is the only non-cholinesterase inhibitor (non-ChEI) drug currently approved for the treatment of $\mathrm{AD}$, particularly for the cognitive symptoms of Alzheimer's disease, covering memory loss, confusion, and problems with thinking and reasoning (Figure 7).

Both types of drugs may only help lessen or stabilize symptoms. Memantine improves memory, attention, language, and the ability to perform simple tasks in the treatment of moderate to severe stages of $\mathrm{AD}$. It can be used either alone or with other $\mathrm{AD}$ drugs that regulate the activity of glutamate, another chemical messenger involved in learning and memory. However, it has some disturbing side effects, including headache, constipation, confusion, and dizziness (24).

Types of targets in the discovery/development of new $\mathrm{AD}$ drugs

Various synthetic and natural drugs are in development for dementia, covering a wide range of targets. They are classified by Howes and Perry (2) as follows:

1. New ChEIs; $\beta$-Amyloid (Ab) modulators [bapineuzum$a b$, solanezumab], including $\beta$-and g-secretase inhibitors [semagacestat]

2. Muscarinic and nicotinic receptor ligands

3. AMPA (amino-3-hydroxy-5-methyl-4-isoxazole propionic acid) and NMDA receptor modulators [neramexane]

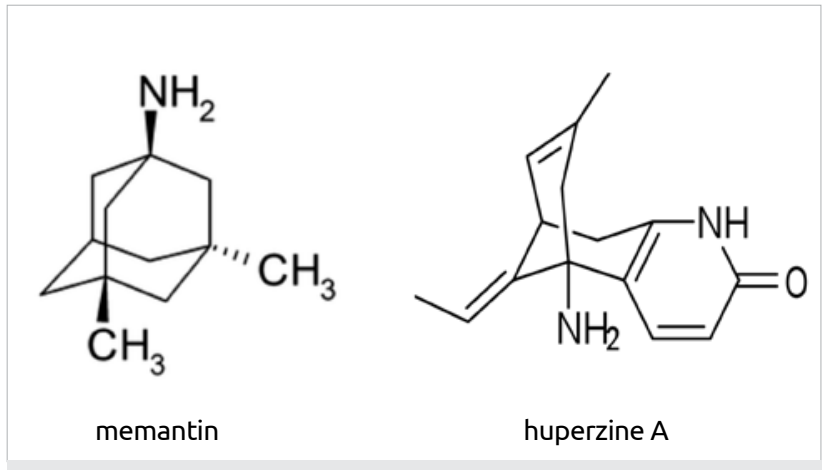

Figure 7. Structures of memantine and huperzine $A$

4. Cytokine synthesis inhibitors

5. Astrocyte modulators [arundic acid]

6. COX-2 (cyclo-oxygenase-2) inhibitors [celecoxib]

7. Calcineurin modulators

8. ApoE (apolipoprotein E) modulators

9. Tau protein modulators, including GSK3 (glycogen synthase kinase 3) inhibitors

10. Microtubule stabilizers

11. Calcium metabolism modulators

12. Chelating agents

13. Cannabinoid CB1 receptor antagonists

14. Platelet-activating factor (PAF) receptor antagonists

15. Monoamine oxidase (MAO) inhibitors

16. GABA receptor modulators

17. a-synuclein modulators

In addition to the drugs above (2), antioxidants, energy metabolism modulators [latrepirdine, formerly dimebon], neu- 
ronal growth factors, monoclonal antibodies, and gene and stem cell therapies should be considered as potential $\mathrm{AD}$ drugs. In the classification above, drugs that have reached the phase III trial stage are shown in brackets.

\section{Plant Extracts and Phytochemicals as Potential Therapeu- tic Agents in Alzheimer's Disease}

A number of scientific studies have been carried out on medicinal herbs. Herbs have anti-inflammatory, antioxidant, cognitive-enhancing, neuroprotective, and antiaging effects that may be used in the treatment of $\mathrm{AD}$ (25). Anti-inflammatory herbs may reduce inflammation of the brain tissue in $\mathrm{AD}$, such as German chamomile (Matricaria chamomilla), ginseng (Panax ginseng), licorice (Glycyrrhiza glabra), turmeric (Curcuma longa), and white willow bark (Salix alba), which also afforded the active principal of aspirin. Acetylcholine is a neurotransmitter that plays a key role in cognitive function and reasoning. However, the brains of those with mild to moderate Alzheimer's disease, a progressive type of dementia, have abnormally low acetylcholine concentrations. This means that any compound that enhances the cholinergic system in the brain may be useful in treating Alzheimer's disease and similar brain malfunctions. The herbs, such as COX-2 inhibitors, were also reported to inhibit acetylcholinesterase (AChE) for $\mathrm{AD}$ indications (8).

Free radicals occur in body chemistry in processes, such as the destruction of invading organisms by white blood cells. Free radicals might play a role in various diseases, such as arthritis, heart disease, and Alzheimer's disease (AD). When natural enzyme controls fail, free radicals in the body attack lipids, proteins, and nucleic acids. Oxidative stress is one of the first steps of $\mathrm{AD}$, which may play a pathogenic role in its progress.

Plants and their constituents with pharmacological activities may be relevant for the treatment of cognitive disorders, including enhancement of cholinergic function in the central nervous system (CNS) and anti-inflammatory and antioxidant activities. In Ayurvedic and Chinese medicine, numerous plants have been used to treat CNS disorders, indicating the potential for therapeutic use in neurodegenerative diseases, such as AD, Parkinson, and some other diseases (26).

\section{Lamiaceae family plants}

The Lamiaceae or Labiatae (the mint family) is one of the largest families, with around 7000 species worldwide (27). Lamiaceae plants are widely used in traditional medicine since antiquity, especially the aromatic and culinary herbs, such as mint, rosemary, sage, savory, marjoram, oregano, thyme, and lavender. Many members of the family are widely cultivated, owing not only to their aromatic qualities but also their ease of cultivation. Besides those grown for their edible leaves, some are also used for decorative purposes, including catmint (Nepeta), sage (Salvia), yellow-flowered sage (Phlomis), and bugle (Ajuga). Many of these and related species are also important bee plants, providing the nectar and pollen (secreted from glands on the leaves and stems of the plant) are commercially extracted from many species. Menthol and thymol and many other monoterpenes are used in medicine and the food industry.

Some Lamiaceae plant seeds, such as chia (Salvia hispanica L.), are used instead of leaves for food purposes. Many spices have been shown to impart an antioxidative effect in foods (28). The term "spice" is defined as dry plant material that is normally added to food to impart flavor. Lamiaceae plants are rich in terpenoids, not only monoterpenes but also sesqui, di-, and triterpenoids, along with flavonoids and other phenolics (29) having a number of biological activities, including antimicrobial, anti-inflammatory, antioxidant, antiviral, cytotoxic, wound healing, neuroprotective, and anticholinesterase (30).

Members of the Lamiaceae family and their phytochemicals have been studied for pharmacological and some clinical effects relevant to dementia, reviewed by Perry and Howes (30). Among Lamiaceae plants, especially Salvia, Rosmarinus, and Melissa species, have been known to have neuroprotective properties for many years, besides some other Lamiaceae plants, such as Teucrium species, especially T. polium L. Those four mentioned genera were also reported to be used in Anatolia for memory enhancement in a very old book, written in the $17^{\text {th }}$ century by an Ottoman herbalist-physician (31).

Lamiaceae family plants have been used in Turkey as folk medicines (32) to treat various disorders, such as common cold, throat infections, psoriasis, seborrheic eczema, hemorrhage, menstrual disorders, miscarriage, ulcer, spasm, and stomach problems, since ancient times. Lamiaceae plants are represented by 45 genera and 550 species with over 735 taxa in Turkey. From this family, 28 genera are widely distributed, and over 240 species are endemic (29). They have been searched for secondary metabolites, particularly di- and triterpenoids and flavonoids and other phenolic compounds, as well as for the essential oil contents that have various activities-namely antioxidant, anticholinesterase, antimicrobial, anti-inflammatory, and cytotoxic (29).

Table 2 shows potential Lamiaceae plants having anticholinesterase and/or other related activities in the treatment of Alzheimer's disease.

\section{Lavandula species}

In traditional medicine, Lavandula officinalis Chaix ex Villars has been used in neurological disorders, like epilepsy, dementia, depression, and chest and rib pains, in extract form for internal use and in the form of ointment for external use (33). L. officinalis has generally been considered as a medicinal agent with sedative, antidepressive, antispasmodic, antiflatulent, antiemetic, diuretic, anticonvulsant, antibacterial, and general tonic properties (33).

L. officinalis suppressed brain NO level and showed low antiepileptic activity in a study carried out by Rahmati et al. 

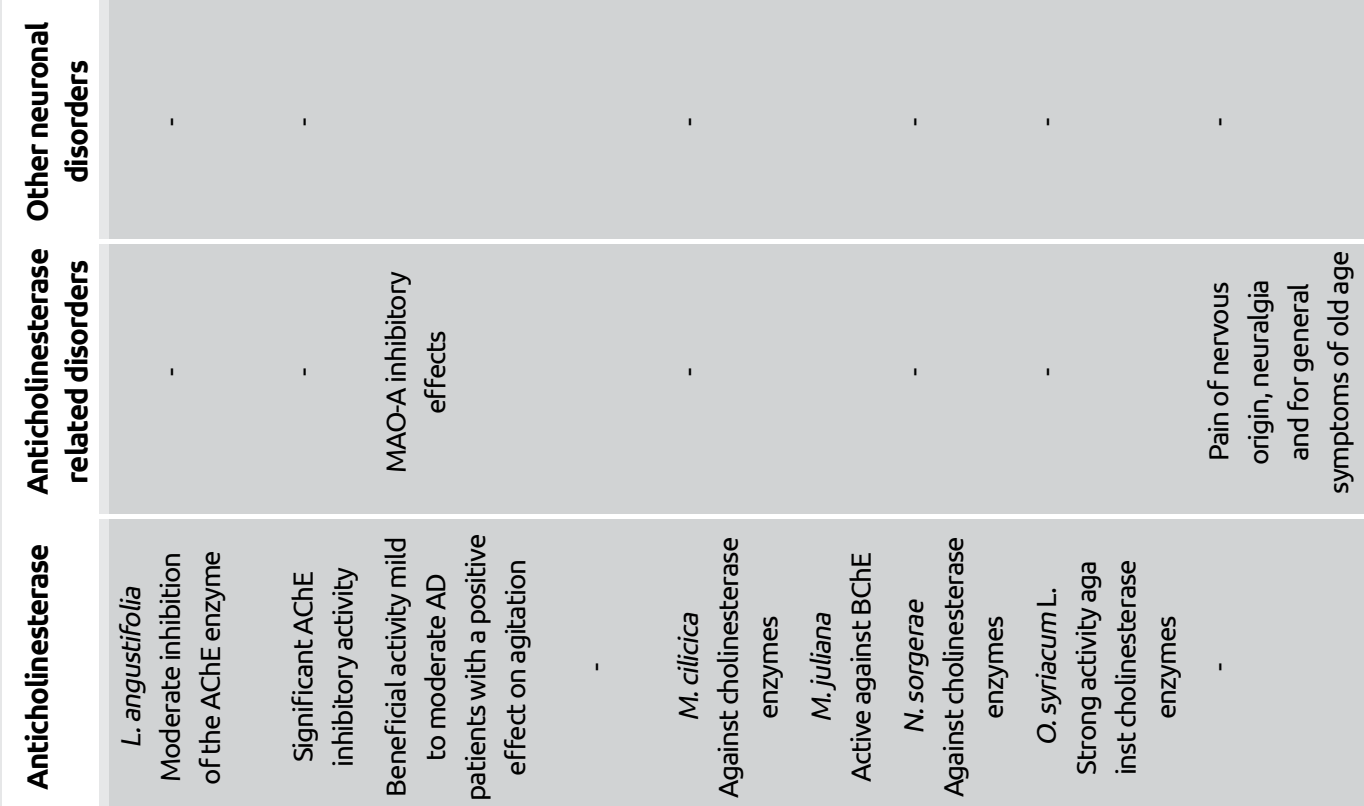

范
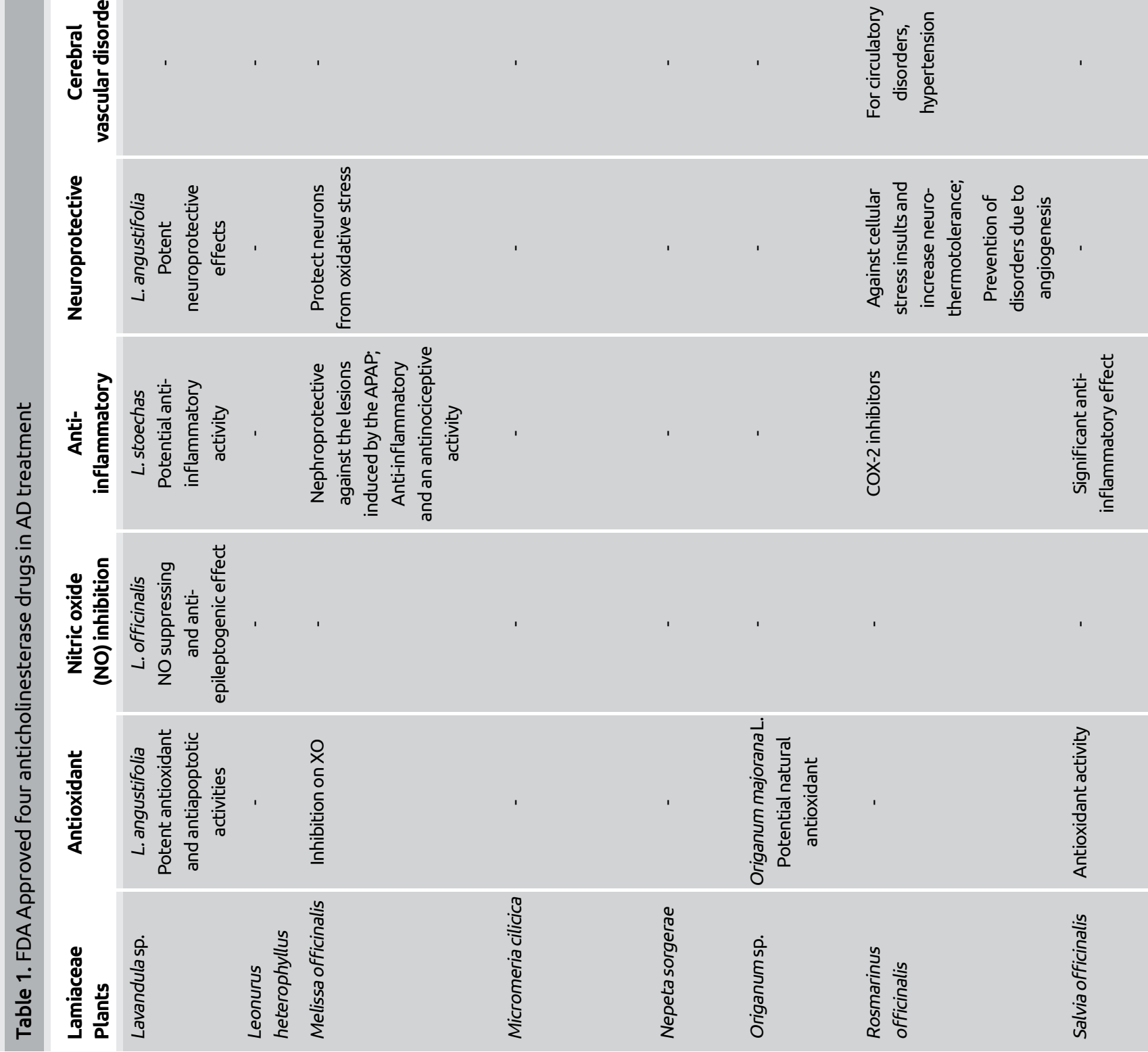


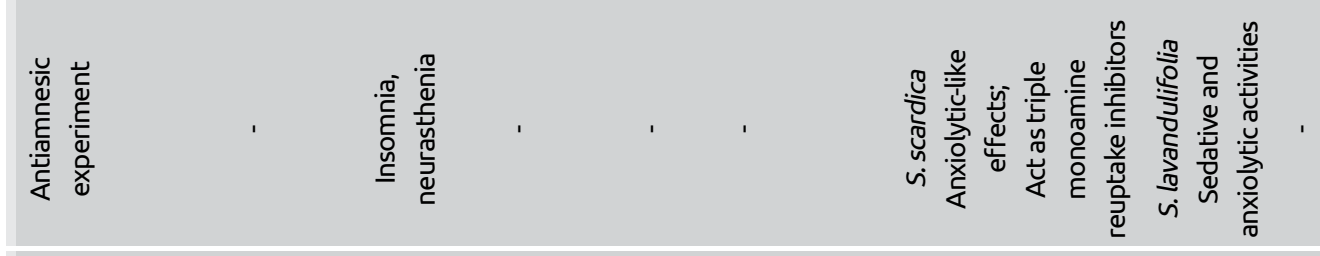
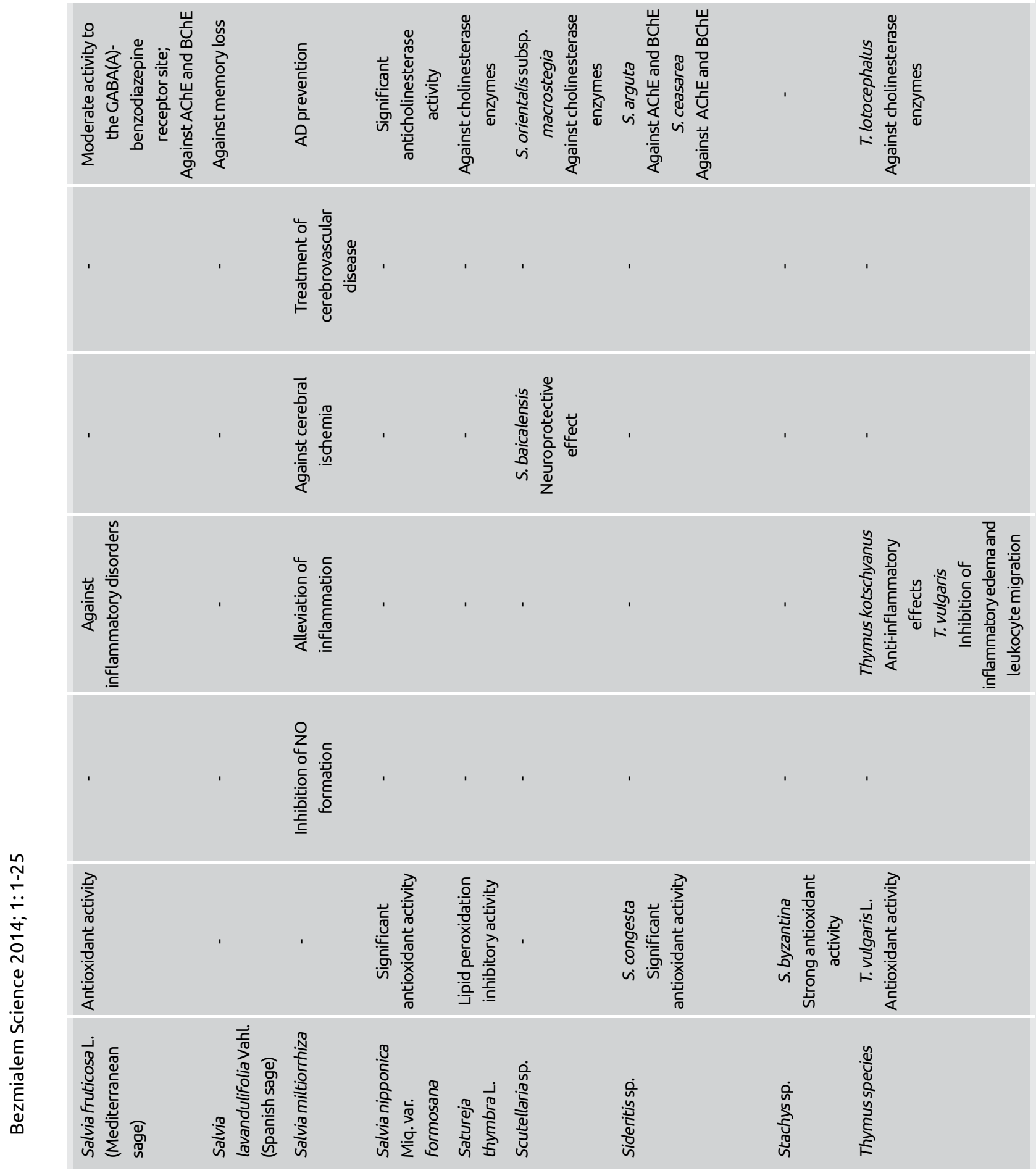
(34), suggesting that the NO-suppressing effect of the extract is partly responsible for antiepileptic property of $L$. officinalis.

In a study, L. stoechas L. was found to be active against dermatophyte strains and showed potential anti-inflammatory activity, since it inhibited NO production at concentrations without affecting cell viability. Therefore, L. stoechas may be considered as a potential agent in the treatment of AD (35), as well as L. viridis L'Hér extracts.

The genus Lavandula (known as lavanta in Turkish) is represented by two species in Turkey: L. angustifolia Mill. and $L$. stoechas with two subspecies. Triterpenoids from the roots of L. stoechas L. ssp stoechas L. with cytotoxic properties were reported by Topcu et al. (36).

In another study, in scopolamine-treated rats, lavender essential oils showed potential antioxidant and antiapoptotic activities. The study showed that antioxidant and antiapoptotic activities are the major mechanisms for their potent neuroprotective effects against scopolamine-induced oxidative stress in the rat brain (37). Aqueous and methanolic extracts of $L$. angustifolia have been shown to possess significant acetylcholinesterase inhibitory activity in a dose-dependent manner (38) (Table 2).

\section{Leonurus heterophyllus L.}

L. heterophyllus is known as 'Ich mau thao' (motherwort) in Vietnamese traditional medicine. L. heterophyllus ethanol extract has shown significant AChE inhibitory activity (39). Also, its seven isolates were investigated in vitro for their anticholinesterase activity using the mouse cortex AChE enzyme, and two of them, leoheteronin A and leopersin G (Figure 8), were found to be potent in the inhibition of AChE.

\section{Melissa officinalis L.}

Melissa officinalis (Lemon balm, oğul otu in Turkish) (Figure 9) is one of the important Lamiaceae family plants. Its essential oil is used as an antibacterial, sedative, and spasmolitic agent, and research on oil of lemon balm has continued intensively (40). Lemon balm can also temporarily improve cognitive decline as well as improve the mood for Alzheimer's patients. A study addressing the use of lemon balm for AD concluded that $M$. officinalis is one of several plants that may be useful in the prevention and treatment of $\mathrm{AD}$ due to its ability to inhibit AChE along with antioxidant activity (8).

Akhondzadeh et al. (41) carried out a study on $M$. officinalis extract, which indicated its value in the management of mild to moderate $\mathrm{AD}$ and that it has a positive effect on agitation in patients. Kennedy et al. (42) have suggested the potential of lemon balm to mitigate the effects of stress. Bolkent et al. (43) reported that the administration of $M$. officinalis extract reduced total cholesterol, total lipid, ALT, AST, and ALP levels in serum and LPO levels in liver tissue and increased glutathione levels in the tissue. Therefore, it was suggested that $M$. officinalis extract exerted a hypolipidemic effect and showed a protective effect on the liver of hyperlipidemic rats (40).
M. officinalis extracts have been shown to bind directly to both nicotinic and muscarinic receptors in human brain tissue. Robust anxiolytic effects have also been demonstrated following acute administration to healthy humans. In a study, aromatherapy with $M$. officinalis reduced agitation, because its essential oil attenuates cognitive declines in patients with dementia (44).

M. officinalis has shown protective effects in the PC12 cell line, MAO-A-inhibitory effects, and free radical scavenging properties (45). leoheteronin A

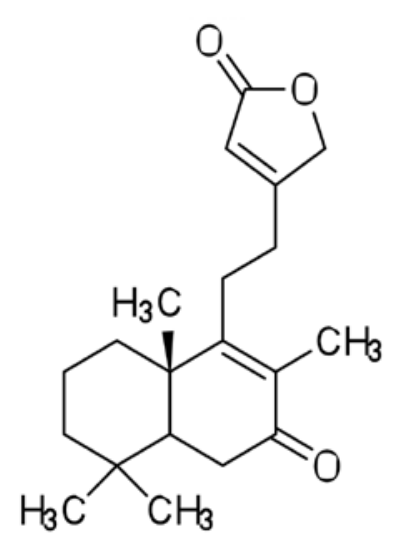

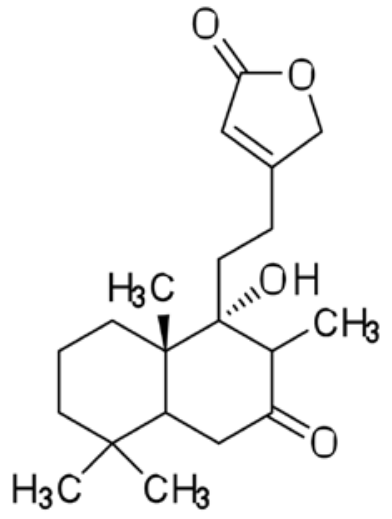

leopersin G
Figure 8. Structures of leoheteronin A and leopersin G

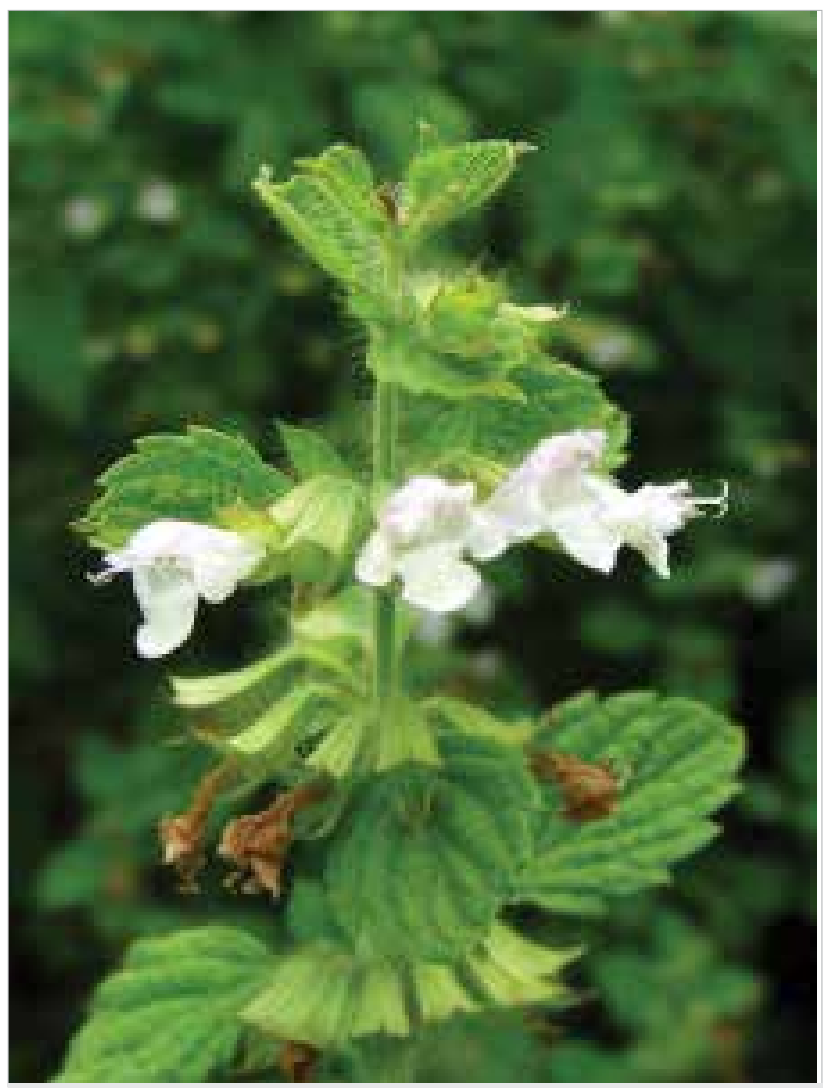

Figure 9. Melissa officinalis L. 

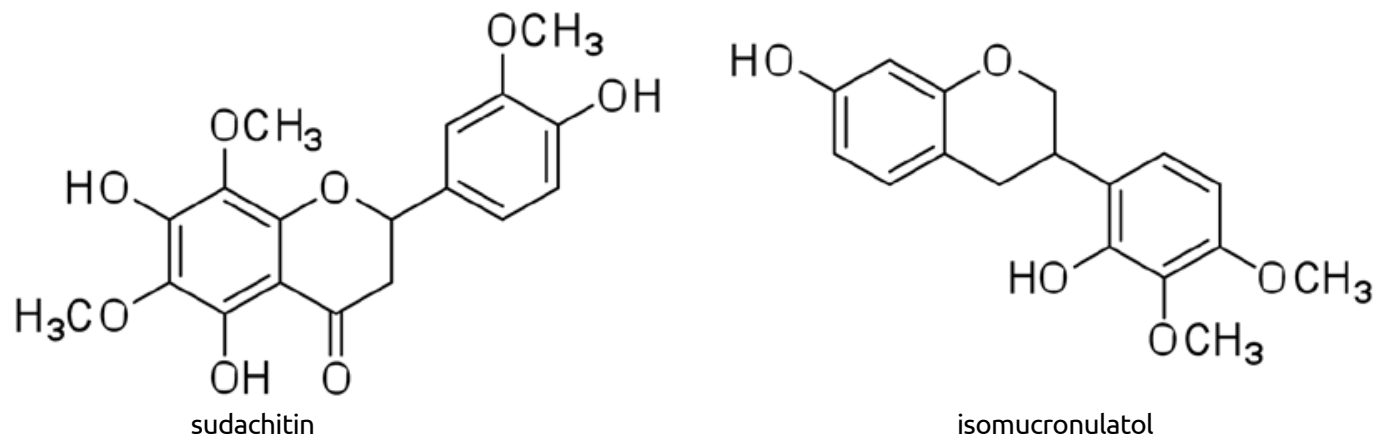

isomucronulato

\section{Figure 10. Structures of flavonoids sudachitin and isomucronulatol}

An aqueous extract of $M$. officinalis has nephroprotective effect against the lesions induced by acetaminophen (APAP) and showed an anti-inflammatory effect on carrageenan-induced pleurisy $(46,47)$.

\section{Micromeria species}

\section{M. cilicica Hausskn. ex P.H. Davis}

M. cilicica (Syn. Clinopodium cilicicum (Hausskn. ex P. H. Davis) Bräuchler \& Heubl) is grown in Mersin, Turkey. Its extracts and seven isolated constituents were tested against both cholinesterase enzymes. While all the tested compounds exhibited only weak inhibition against the AChE enzyme, three of them, including two flavonoids, sudachitin and isomucronulatol (Figure 10), and a triterpene, ursolic acid, exhibited moderate-high inhibition against BChE enzyme (Table 3) (48).

\section{M. juliana (L.) Bentham ex Reichb.}

Acetyl- and butyryl-cholinesterase inhibitory activities of the aerial parts of $M$. juliana were investigated, and the petroleum ether and acetone extracts were found to be moderately active against BChE. Antioxidant activity results, obtained by using a series of antioxidant tests, namely lipid peroxidation inhibition activity (beta-carotene-linoleic acid assay), DPPH radical scavenging, ferric reducing power, and metal chelating capacity, supported potential use of Micromeria species as cholinesterase-inhibitory agents (49).

\section{Nepeta species}

In Turkey, Nepeta species are represented by 41 taxa, of which 18 are endemic. The endemic and non-endemic species of the genus Nepeta mostly grow in East Anatolia and the Taurus mountains. Some Nepeta species are used in folk medicine as a diuretic, diaphoretic, antitussive, antispasmodic, antiasthmatic, febrifuge, emmenagogue, sedative, and spice and herbal tea (50).

In a study, the BChE inhibition activity of the dichloromethane and methanol extracts of $N$. sorgerae Hedge et Lamond, grown in Anatolia (Nemrut mountain), was not found to be high $(13.9 \pm 0.4 \mu \mathrm{g} / \mathrm{mL}$ and $5.3 \pm 0.4 \mu \mathrm{g} /$ $\mathrm{mL} \%$, respectively), but their AChE inhibition activ-

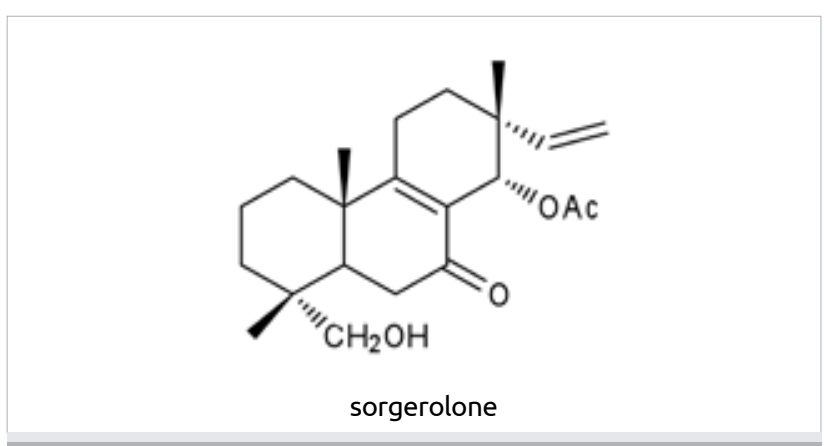

Figure 11. Structure of sorgerolone

66.7 $\pm 0.7 \mu \mathrm{g} / \mathrm{mL} \%$, respectively). The isolated new compound isopimarane diterpene sorgerolone (Figure 11) showed high inhibition against $\mathrm{AChE}\left(\mathrm{IC}_{50=} 17.8 \mu \mathrm{g} / \mathrm{mL}\right)$ and BChE enzymes $\left(\mathrm{IC}_{50}=120 \mu \mathrm{g} / \mathrm{mL}\right)(50)$.

Extracts of a series Nepeta species have been searched for anticholinesterase and antioxidant activities and exhibited fairly promising results, except for $N$. baytopii Hedge et Lamond and $N$. fissa C. A. Meyer. Inhibition was observed, particularly against $\mathrm{AChE}$ enzyme, ranging from $55.91 \%$ to $74.12 \%$, probably due to their rich contents in phenolics (rosmarinic acid) and triterpenoids (oleanolic and ursolic acids and their derivatives). The studies are going to be completed by our group. Terpenoids and steroids as nepetalic acid esters were obtained from $N$. caesarea Boiss., besides several known terpenoids and rosmarinic acid, which is a common phenolic compound with high antioxidant activity in some Lamiaceae plants (51).

\section{Origanum species}

The genus Figure 11 (sorgerolone) Origanum (Lamiaceae), known as kekik in Turkish, is represented in Turkey by 23 species with 32 taxa, 21 being endemic. Origanum species have been referred to as one of the memory-enhancing plants. They also have antioxidant, antibacterial, anti-inflammatory, and antispasmodic effects (52).

O. ehrenbergii Boiss and O. syriacum L. oils were evaluated for their anticholinesterase, NO production-inhibitory, and antioxidant activities. O. ehrenbergii oil exhibited strong ac- 
Table 3. Potential pure compounds isolated from Lamiaceae plants having anticholinesterase and/or other related activities in the treatment of Alzheimer's Disease

\begin{tabular}{|c|c|c|c|c|c|}
\hline Plant name & Pure Compound & $\begin{array}{c}\text { Antioxidant } \\
\text { activity }\end{array}$ & $\begin{array}{c}\text { AChE } \\
\text { (Inhibition \%) } \\
100 \mu \mathrm{g} / \mathrm{mL} \text { or } \\
\mathrm{IC}_{50}(\mu \mathrm{g} / \mathrm{mL} \text { ) }\end{array}$ & $\begin{array}{c}\text { BChE } \\
\text { (Inhibition \%) } \\
100 \mu \mathrm{g} / \mathrm{mL} \text { or } \\
\text { IC }_{50}(\mu \mathrm{g} / \mathrm{mL} \text { ) }\end{array}$ & $\begin{array}{c}\text { Anti- } \\
\text { inflammatory }\end{array}$ \\
\hline Salvia fruticosa & $\begin{array}{c}\text { oleanolic acid } \\
\text { ursolic acid } \\
\text { a-amyryltetracosanoate } \\
\text { 3-acetylsitosterol }\end{array}$ & $\begin{array}{c}37.35 \pm 1.23^{\mathrm{a}} \\
31.14 \pm 0.92^{\mathrm{a}} \\
0.22 \pm 0.02^{\mathrm{b}} \\
57.48 \pm 1.54^{\mathrm{a}}\end{array}$ & $\begin{array}{l}77.26 \pm 0.59 \\
75.87 \pm 0.92 \\
45.19 \pm 0.75 \\
54.70 \pm 0.75\end{array}$ & $\begin{array}{l}20.16 \pm 0.31 \\
32.21 \pm 0.88 \\
38.89 \pm 0.78 \\
54.45 \pm 0.37\end{array}$ & \\
\hline $\begin{array}{l}\text { S. nipponica var. } \\
\text { formosana }\end{array}$ & $\begin{array}{c}\text { taxodione } \\
(+) \text {-valeranone } \\
\text { nubiol } \\
\text { methyl rosmarinate } \\
\text { rosmarinic acid } \\
\text { salvianolic acid B } \\
\text { 3-sitosteroyl-3-O- } \beta \text {-D-glucoside } \\
\text { 3-epi-corosolic acid } \\
\text { ursolic acid } \\
\text { 2a,3a-23-trihydroxy-urs-12- } \\
\text { en-28-oic acid } \\
\text { oleanolic acid 3-O-ferulate } \\
\text { caffeic acid methyl ester } \\
\text { vanillic acid }\end{array}$ & $\begin{array}{l}23.86 \pm 2.17^{b} \\
-9.16 \pm 5.11^{b} \\
11.11\left(I C_{50}\right)^{c} \\
11.89\left(I C_{50}\right)^{c} \\
26.00 \pm 1.57^{b} \\
14.64 \pm 4.23^{b} \\
0.71 \pm 0.05^{b} \\
6.18 \pm 0.19^{b} \\
2.13 \pm 0.44^{b} \\
0.44 \pm 0.05^{b} \\
22.48\left(I C_{50}\right)^{c} \\
11.76 \pm 1.01^{b} \\
23.82\left(I C_{50}\right)^{c}\end{array}$ & & $\begin{array}{l}2.88\left(I C_{50}\right) \\
114.12\left(I C_{50}\right) \\
77.15\left(I C_{50}\right) \\
108.51\left(I C_{50}\right) \\
46.70\left(I C_{50}\right)\end{array}$ & $\begin{array}{l}36.68 \pm 4.36^{\mathrm{e}} \\
10.22 \pm 2.98^{\mathrm{e}} \\
1.46 \pm 0.42^{\mathrm{e}} \\
6.66 \pm 0.87^{\mathrm{e}} \\
2.03 \pm 0.37^{\mathrm{e}} \\
12.14 \pm 0.82^{\mathrm{e}} \\
1.29 \pm 0.15^{\mathrm{e}} \\
0.33 \pm 0.12 \\
6.00 \pm 0.65^{\mathrm{e}} \\
1.23 \pm 0.30^{\mathrm{e}} \\
20.67 \pm 3.00^{\mathrm{e}} \\
17.79 \pm 2.24^{\mathrm{e}}\end{array}$ \\
\hline S. potentillifolia & $\begin{array}{l}a \text {-pinene } \\
\beta \text {-pinene }\end{array}$ & & $\begin{array}{c}87.2 \pm 0.50 \\
\text { NA }\end{array}$ & $\begin{array}{c}17.5 \pm 1.18 \\
\text { NA }\end{array}$ & \\
\hline S. poculata & $\begin{array}{c}\text { ursolic acid } \\
\text { 5-hydroxy } 7,4^{\prime} \text { dimethoxyflavone } \\
\text { eupatilin } \\
\text { salvigenin } \\
\text { sclareol } \\
\text { B-sitosterol }\end{array}$ & $\begin{array}{l}94.43\left(I C_{50}\right)^{b} \\
71.65\left(I C_{50}\right)^{b} \\
44.80\left(I C_{50}\right)^{d} \\
59.14\left(I C_{50}\right)^{b} \\
22.34\left(I C_{50}\right)^{d} \\
78.46\left(I C_{50}\right)^{b} \\
78.68\left(I C_{50}\right)^{d} \\
48.74\left(I C_{50}\right)^{b} \\
>100\left(I C_{50}\right)^{d} \\
>100\left(I C_{50}\right)^{b} \\
>100\left(I C_{50}\right)^{d}\end{array}$ & $\begin{array}{l}50.72 \pm 0.53 \\
\text { NA } \\
0.94 \pm 0.63 \\
\text { NA } \\
\text { NA } \\
\text { NA }\end{array}$ & $\begin{array}{l}66.70 \pm 0.89 \\
\mathrm{NA} \\
32.22 \pm 0.24 \\
7.96 \pm 0.67 \\
7.99 \pm 0.73 \\
6.80 \pm 0.82\end{array}$ & \\
\hline Micromeria cilicica & $\begin{array}{c}\text { isothymonin 4'-methyl ether } \\
\text { sudachitin }\end{array}$ & 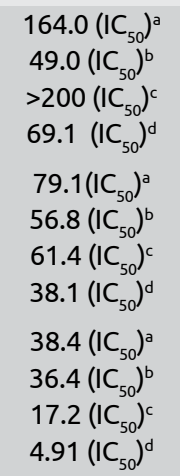 & $5.25 \pm 0.87$ & $26.0 \pm 0.99$ & \\
\hline
\end{tabular}




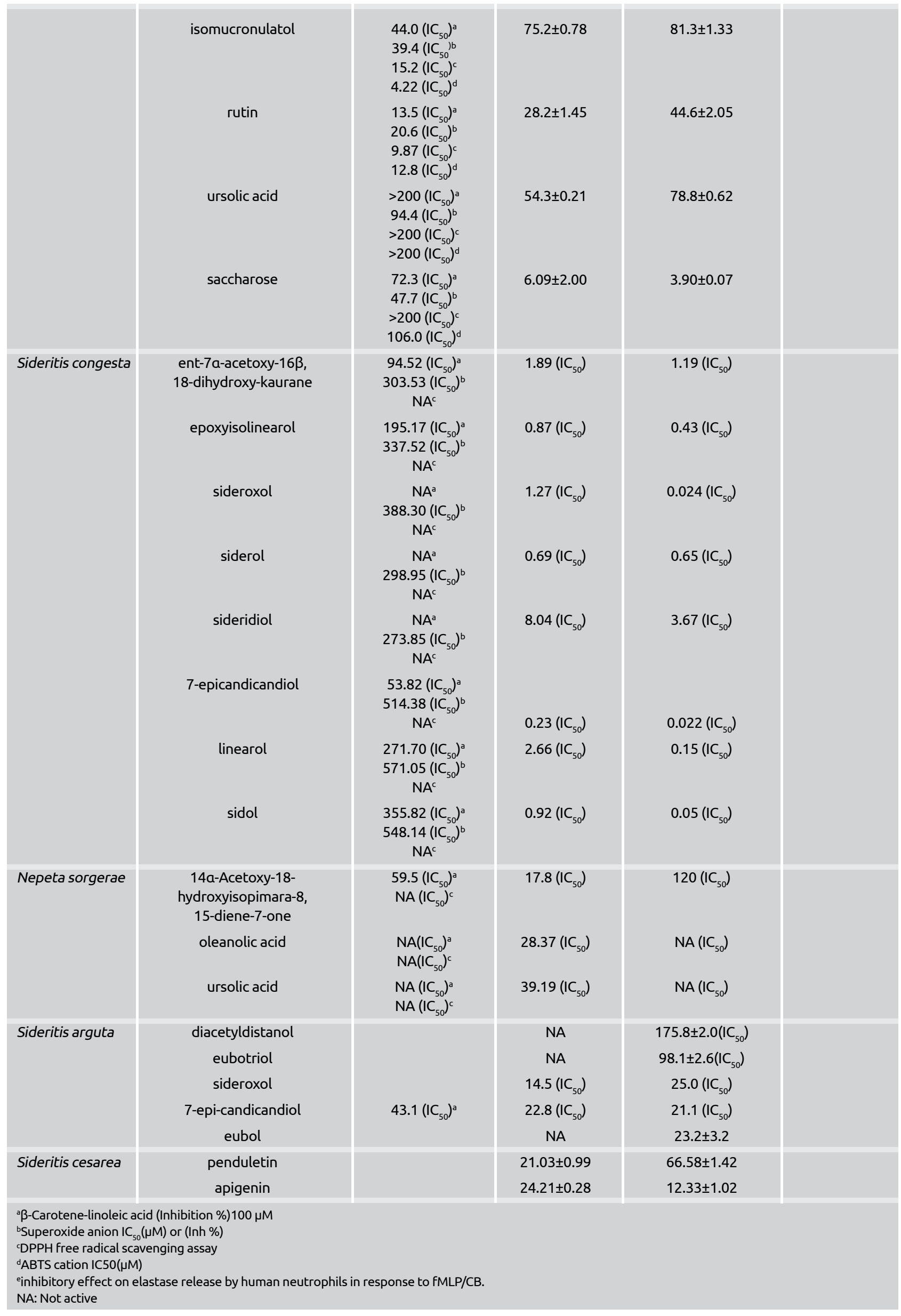


tivity against both cholinesterases, with $\mathrm{IC}_{50}$ values of $0.3 \mu \mathrm{g} /$ $\mathrm{mL}$. Essential oil of O. syriacum also exhibited high activity. Interestingly, O. ehrenbergii oil inhibited NO production in the murine monocytic macrophage cell line RAW 264.7, with an $\mathrm{IC}_{50}$ value of $66.4 \mu \mathrm{g} / \mathrm{mL}$. In addition, both $O$. ehrenbergii and $O$. syriacum oils moderately inhibited oxidation of linoleic acid after incubation. Furthermore, O. ehrenbergii showed strong scavenging effects on $\mathrm{DPPH}$, with an $\mathrm{IC}_{50}$ value of $0.99 \mu \mathrm{g} / \mathrm{mL}$. All the data together suggest that O. ehrenbergii and $O$. syriacum oils might be used as valuable new flavors in functional foods and nutraceutical products, with particular relevance to supplements for the elderly (53).

In another study, essential oil of marjoram (O. majorana L.) had significant potential as a natural antioxidant and antiAChE agent (54).

\section{Rosmarinus officinalis $\mathrm{L}$.}

$R$. officinalis (known as biberiye/kuşdili in Turkey) (Figure 12 ) is a dietary herb that possesses high antioxidant activity and was first marketed as a source of natural antioxidants. It has been used as a medicinal herb since early times, and it has received increasing attention due to its antimicrobial, anti-inflammatory, and antioxidative constituents. Rosemary contains a large number of compounds consisting of phenolics and abietane diterpenes, which are responsible for its antioxidant and cytotoxic activity, such as rosmarinic acid (Figure 13), carnosic acid, and carnosol (Figure 14).

R. officinalis is used in connection with $\mathrm{AD}$ and dementia for general symptoms of old age, debility, and fatigue. It was also applied for neuralgia, indigestion, pain of nervous origin, circulatory disorders, and hypertension (55).

In a study (56), rosmarinic acid inhibited $\beta$-secretase 1 enzyme, which is beta-site amyloid precursor protein-cleaving enzyme 1 (BACE1), in a non-competitive manner. It was also found in the same study to exhibit weaker inhibition against

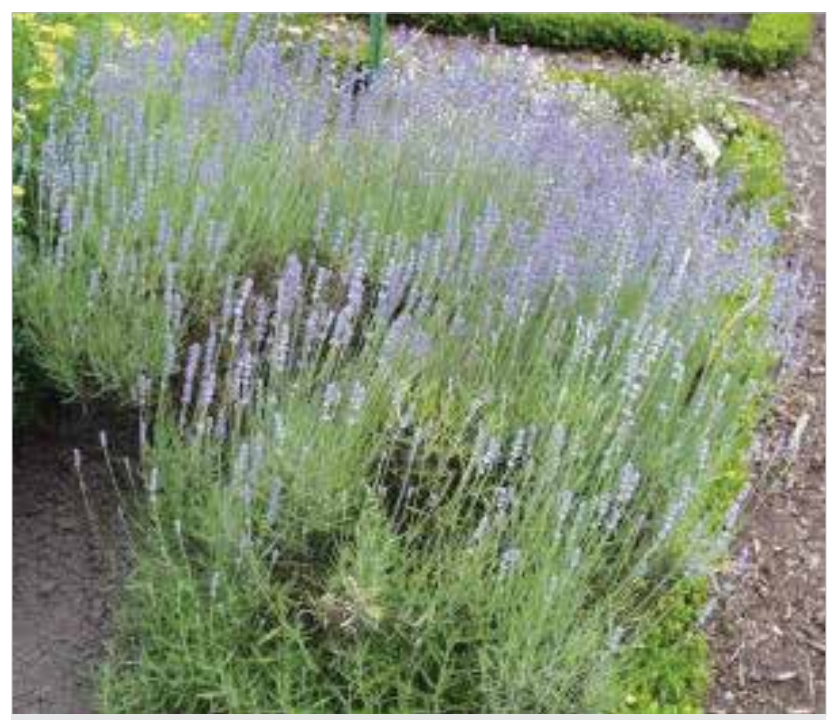

Figure 12. Rosmarinus officinalis L. other enzymes, such as TNF- $\alpha$-converting enzyme (TACE), acetylcholinesterase (AChE), chymotrypsin, and elastase, along with luteolin, indicating that they were relatively specific inhibitors of BACE1.

The anticholinesterase activity of the essential oil of $R$. officinalis most likely depends on a synergistic mechanism of oil components. In contrast to the essential oil, the major compound rosmarinic acid (Figure 13) in the methanolic extract of the plant was considered to be responsible for strong antiBChE activity (57).

In another study, treatment with extract of $R$. officinalis in cirrhotic animals modifies the expression of subunits of the NMDA receptor, with an improvement in hepatocellular function due to the presence of antioxidant compounds and flavonoids (58). $R$. officinalis is able to protect neuronal cells against hydrogen peroxide-induced injury, and it is suggested that $R$. officinalis might potentially serve as an agent for prevention of several human neurodegenerative diseases caused by oxidative stress and apoptosis (59).

The downregulation effect of $R$. officinalis polyphenols on cellular stress proteins in rat pheochromocytoma PC12 cells was investigated, and results suggested that an abietane diterpene, carnosic acid (Figure 14); a stilbene, rosmarinic acid (Figure 13); and a flavone, luteolin (Figure 15) may modulate the neuroprotective defense system against cellular stress (60).

Activated glutathione metabolism participates in protective effects of carnosic acid against oxidative stress in neuronal HT22 cells (61). Carnosic acid is also involved in the synthesis of nerve growth factor (NGF), which is necessary for the growth and maintenance of nerve tissue. Carnosic acid and carnosol (Figure 14) have the potential to protect cortical neuronal cells by activation of the Keap1/Nrf2 pathway (62).

Some Salvia species, particularly S. officinalis L. and S. triloba L., showed similar chemical composition to $R$. officinalis. However, $R$. officinalis leaves are especially much more rich in carnosic acid and carnosol, which are the main abietane diterpenes responsible for prevention of membrane damage and vascular brain circulation, with high antioxidant and neuroprotective properties.

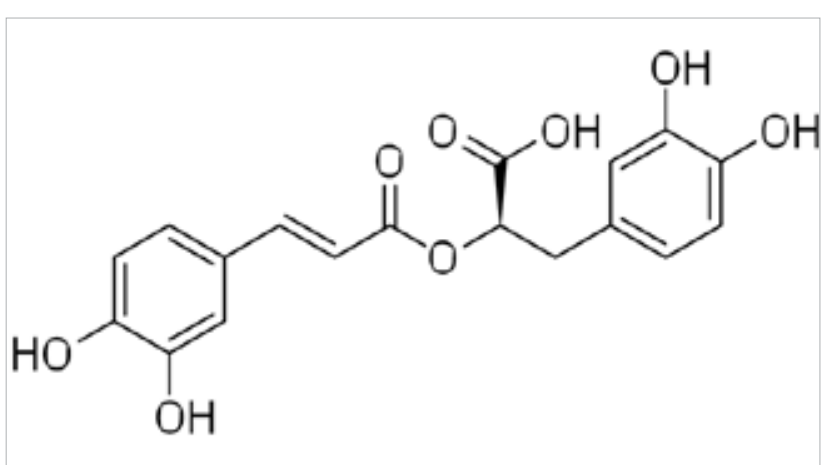

Figure 13. Structure of rosmarinic acid 
A patented study showed that carnosic acid protects neurons both in vitro and in vivo through activation of the Keap1/Nrf2 pathway via S-alkylation of targeted cysteines on Keap1 (63).

The alcoholic extract of $R$. officinalis at 150 and $300 \mathrm{mg} / \mathrm{kg}$ modulated the short- and long-term memories of mice in a social recognition and inhibitory avoidance task, respectively. This modulatory effect was shown to improve learning and memory processes (64).

According to Duke's claim in 2007-"If a synthetic COX-2 inhibitor could prevent Alzheimer's Disease, so could a natural COX-2 inhibitor"-rosemary should be considered a good agent for the treatment of $\mathrm{AD}$ due to the presence of the following natural COX-2 inhibitors (65) in its content: namely, the monoterpenes thymol, carvacrol, and eugenol (Figure 16); a flavone, apigenin (Figure 15); the triterpenoids olea- nolic acid and ursolic acid (Figure 17); and several phenolic compounds. In fact, in addition to Rosmarinus species, many aromatic culinary herbs of Lamiaceae plants, especially Salvia, Mentha, Thymus, and Origanum species, contain the monoterpenic compounds mentioned above.

\section{Salvia species}

One of the most well-known Lamiaceae family plants is the genus Salvia, which has wide distribution, with nearly 1000 species in three regions of the world: Central and South America (500 spp.), Central Asia/Mediterranean (250 spp.), and Eastern Asia (90 spp.) (66). Salvia (sage) species have been used since ancient times in folk medicine for cognitive brain function, along with various biological activities. Sage extracts possess antioxidant, estrogenic, and anti-inflammatory properties, which may help strong anticholinesterase effects by inhibiting both butyryl- and acetyl-cholinesterases (67).<smiles>CC(C)c1cc2c(c(O)c1O)C13CCC[C@@](C)(O)C1CC(O2)O3</smiles><smiles>CC(C)c1cc2c(c(O)c1O)[C@@]1(C)CCC[C@](C)(C(C)C)[C@@H]1CC2</smiles>

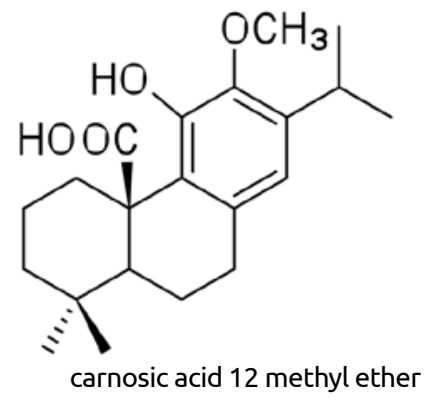

Figure 14. Structures of carnosol, carnosic acid and carnosic acid 12 methyl ether<smiles>O=c1cc(-c2ccc(O)cc2)oc2cc(O)cc(O)c12</smiles>

Figure 15. Structures of apigenin and luteolin<smiles>CC(C)[C@H]1CC[C@@H](C)C[C@H]1O</smiles>

menthol<smiles>Cc1ccc(C(C)C)c(O)c1</smiles>

thymol<smiles>Cc1ccc(C(C)C)cc1O</smiles>

carvacrol<smiles>C=CCc1ccc(O)c(OC)c1</smiles>

eugenol 


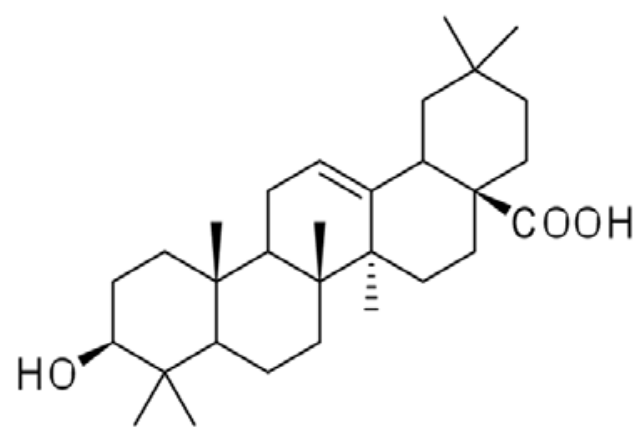

oleanolic acid

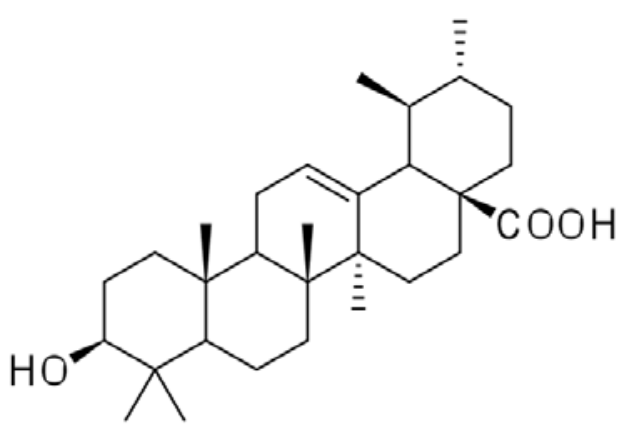

ursolic acid

Figure 17. Structures of most common two triterpenoids in Lamiaceae family plants

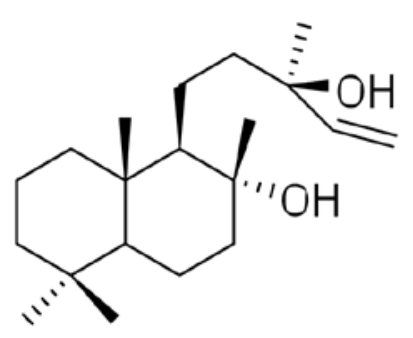

sclareol

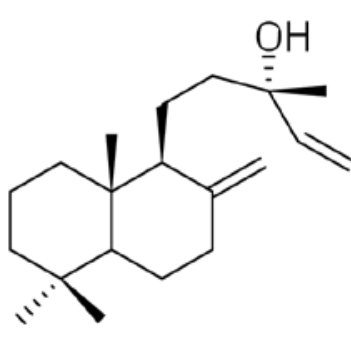

manool
Figure 18. Structures of labdane diterpenoids sclareol and manool

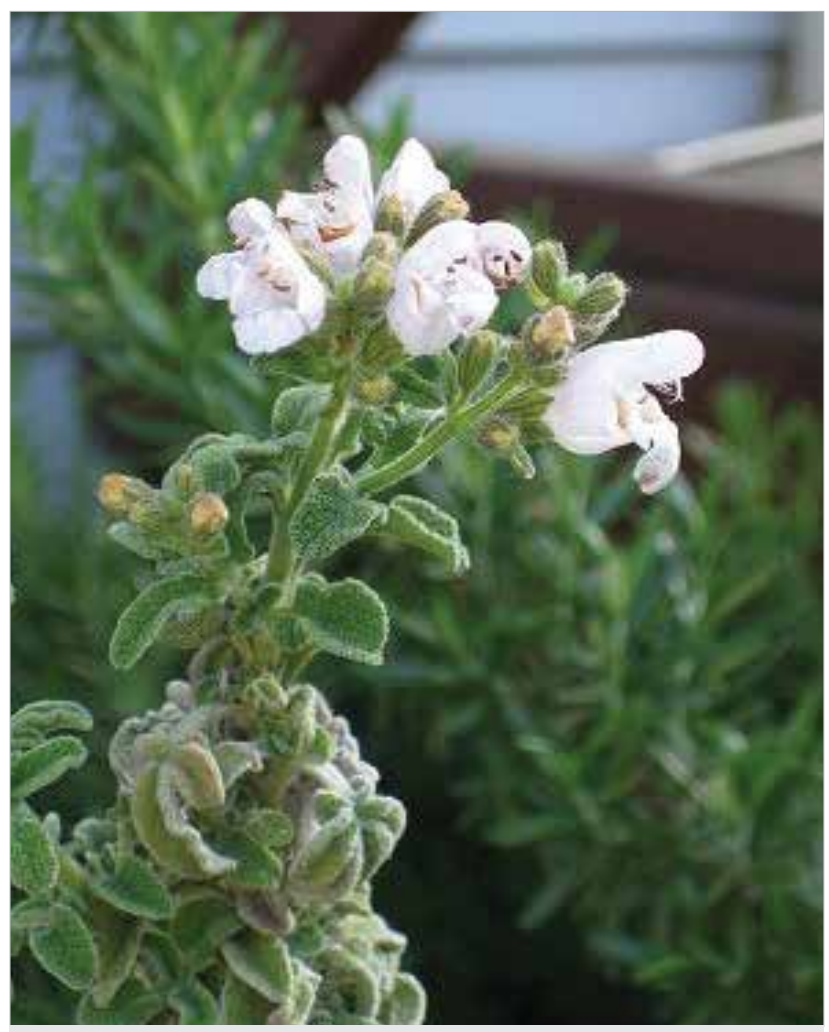

Figure 19. Salvia fruticosa Mill. (S. triloba L.)

The genus Salvia is a huge and important source, rich in terpenoids and flavonoids and other phenolics with antioxidant, anti-tuberculous, anti-inflammatory, neuroprotective, and<smiles>CC(C)C1CCC2(C)CCC1O2</smiles>

1,8-cineole (eucalyptol)

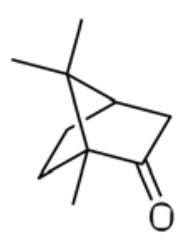

camphor

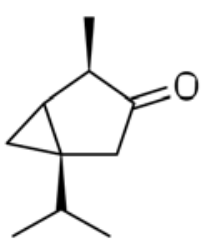

a-thujone

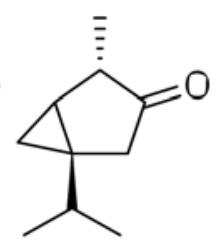

$\beta$-thujone
Figure 20. Structures of some monoterpenoids found in Salvia species

anticholinesterase properties (68). Species of this genus, such as $S$. officinalis, possess significant pharmacological activities as well as economic value.

Some Salvia species (S. officinalis, S. lavandulifolia L.) have been used against memory loss in Europe. The anticholinesterase and anti-Alzheimer activities of Salvia species have been investigated for the last 15 years by some researchers (69) in the world, including several groups from Turkey (70).

Sage has a reputation in traditional European medicine with two species-S. officinalis and S. lavandulifolia-especially the aerial parts. In Europe, S. sclarea L. also has an important place in the food industry with its nice aroma and high antioxidant properties. In traditional Chinese medicine, $S$. miltiorrhiza Bunge roots have effects on improving memory/brain circulation. Salvia is also reported to have antioxidant, estrogenic (71), and anti-inflammatory properties (72). Oxidative stress has been strongly implicated in the pathophysiology of neurodegenerative disorders, such as Alzheimer's disease (AD) (69).

Many studies support traditional uses of European Salvia species grown in Europe, with some of their components reported as follows: cholinesterase inhibition by the monoterpenoids of the essential oil and the extracts from $S$. officinalis and S. lavandulifolia, antioxidant (73) and anti-inflammatory activity of S. lavandulifolia oil (74) and di- and triterpenoids from S. fruticosa Mill. (75), as well as diterpenoids with acetylcholinesterase inhibitory activity from a Chinese sage, $S$. miltiorrhiza (76). 


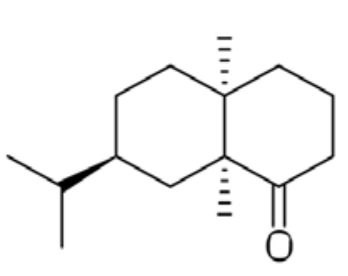

valeranone<smiles>C=C(C)CCC=C(C)CCC1C=CC(=C)CC1C</smiles>

germacrene $D$

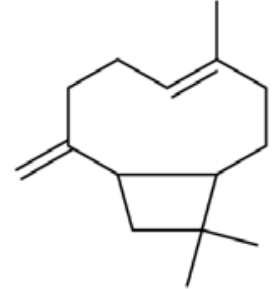

$\beta$-caryophyllene

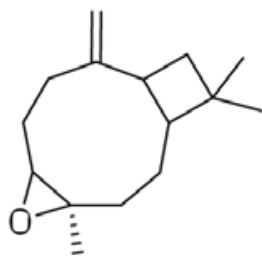

caryophyllene oxide

Figure 21. Structures of sesquiterpenoids

In a study, 56 extracts prepared by organic solvents from 14 Salvia species growing in Turkey were studied for anticholinesterase activity. The most active extracts at $1 \mathrm{mg} / \mathrm{mL}$ for AChE inhibition were observed to be a petroleum ether extract of S. albimaculata Hedge and Huber-Morath (89.4\%) and a chloroform extract of $S$. cyanescens Boiss. et Bal. $(80.2 \%)$, while ethyl acetate extracts of $S$. frigida Boiss. and $S$. migrostegia Boiss and Bal., chloroform extracts of $S$. candidissima Vahl ssp. occidentalis Hedge and S.ceratophylla L., and a petroleum ether extract of $S$. cyanescens were found to inhibit BChE potently $(92.2 \%, 89.6 \%, 91.1 \%, 91.3 \%$, and $91.8 \%$, respectively), (70) as observed in most of the extracts studied of Salvia species growing in Turkey (77-79).

\section{Salvia chionantha Boiss}

The essential oil and methyl ester of hexane extract of Anatolian S. chionantha were analyzed by GC and GC-MS to investigate the volatile constituents and fatty acid composition. Germacrene D (Figure 21) was found to be an important sesquiterpene in its essential oil, and it demonstrated larvicidal activity against Aedes aegypti and Anopheles stephensi as well as effective inhibition of aphid alarm pheromone activity. Moreover, the essential oil showed moderate inhibitory activity against both cholinesterases $\mathrm{AChE}(56.7 \pm 1.9 \%)$ and $\mathrm{BChE}(41.7 \pm 2.9 \%)$, while the hexane extract only exhibited activity against $\mathrm{BChE}$ enzyme at $0.5 \mathrm{mg} / \mathrm{mL}$ concentration $(63.1 \pm 0.8 \%)(78)$. Hence, the essential oil may be useful as a moderate anticholinesterase agent, particularly against AChE enzyme.

\section{Salvia chrysophylla Stapf.}

Sclareol (Figure 18), a labdane diterpene, was found in a number of Salvia species and also in many plant species belonging to other families. It was first isolated from S. sclarea L. and then from some other Salvia species, including S. chrysophylla, in a recent study, which reports its high anticholinesterase activity against both AChE and BChE enzymes, by Çulhaoğlu et al. (79). Sclareol also showed significant cytostatic and cytotoxic effects against leukemic cell lines, and it was found to induce cell cycle arrest and apoptosis (80).

\section{Salvia fruticosa Mill. (S. triloba L.)}

S. fruticosa (synonym; S. triloba) (Figure 19) tea, called "Adaçayı" or "Elmaçayı," is commonly used to cure colds and stomach ache (73). In Anatolian folk medicine, the leaves of

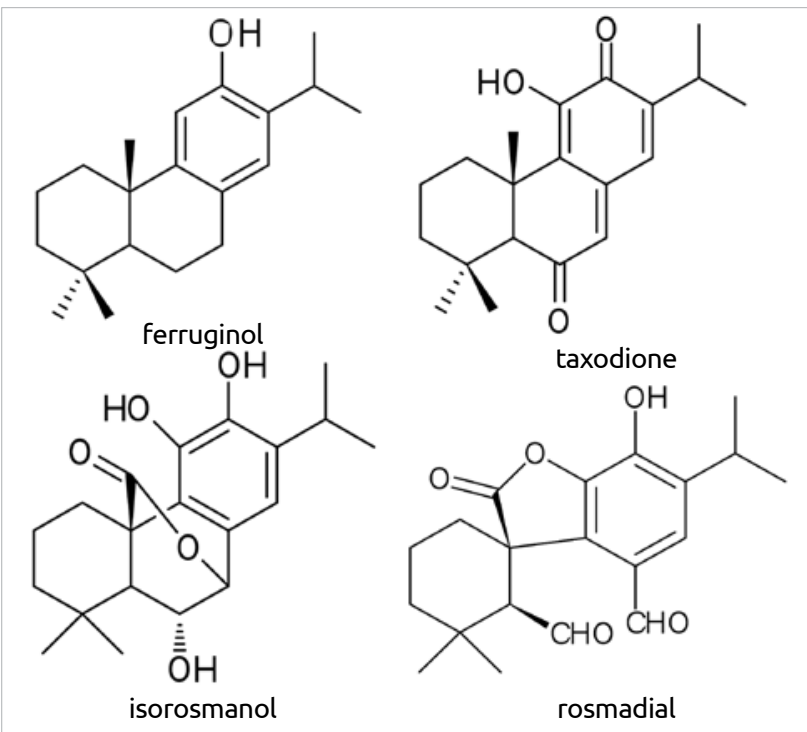

Figure 22. Structures of abietane diterpenoids

and it is one of the plants used for memory enhancing and is neuroprotective in Anatolia (75).

Many studies on the essential oil of $S$. fruticosa reported 1,8 -cineole to be the main component, followed by camphor, $\alpha$-thujone, $\beta$-thujone (Figure 20), and $\beta$-caryophyllene (Figure 21). The species is known to contain biologically active sesquiterpenes and diterpenes, besides the high content of oxygenated monoterpenes (75).

In an evaluation of cholinesterase inhibitory and antioxidant properties of wild and cultivated samples of $S$. fruticosa by activity-guided fractionation, S. fruticosa extracts showed moderate anti-cholinesterase activity (73). However, one of our very recent studies, a methanol extract of $S$. fruticosa showed strong activity against both $\mathrm{AChE}$ and BChE as well as strong antioxidant activity (75).

On the other hand, ethanolic extract of $S$. fruticosa had moderate activity the GABA (A)-benzodiazepine receptor site (81), and furthermore, the ethanol extract of $S$. fruticosa was found to be active in an antiamnesic experiment (82).

Salvia fruticosa Mill. (known as elma çalbasi in Anatolia) extracts afforded six abietane diterpenoids (carnosol, carnosic 

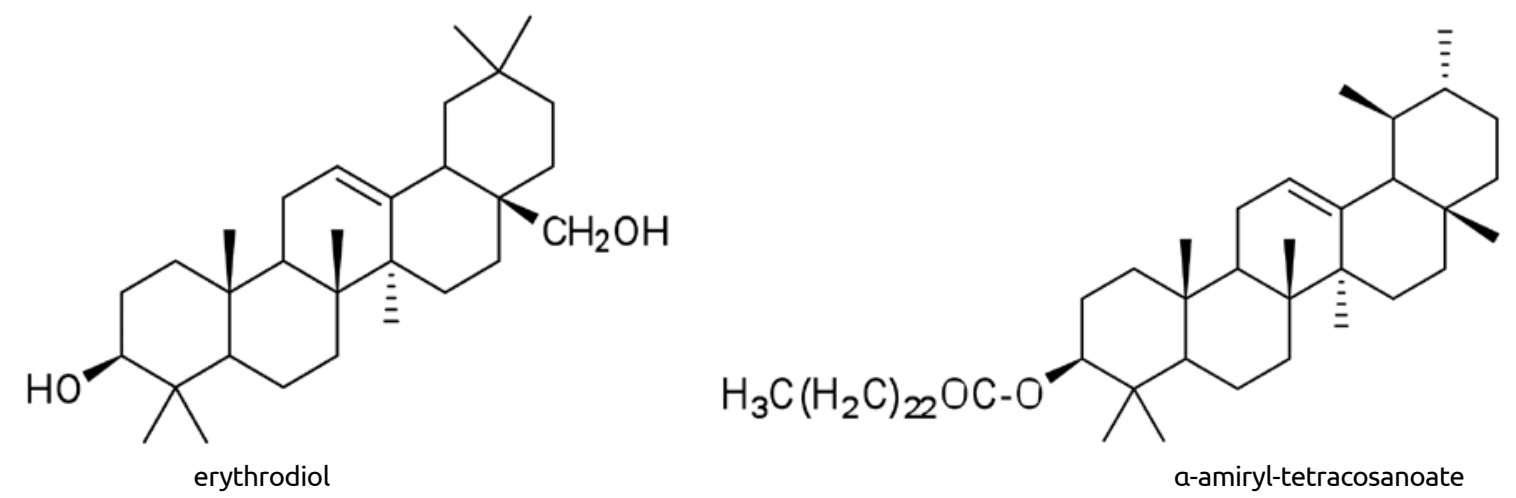

Figure 23. Structures of erythrodiol and a-amiryl-tetracosanoate

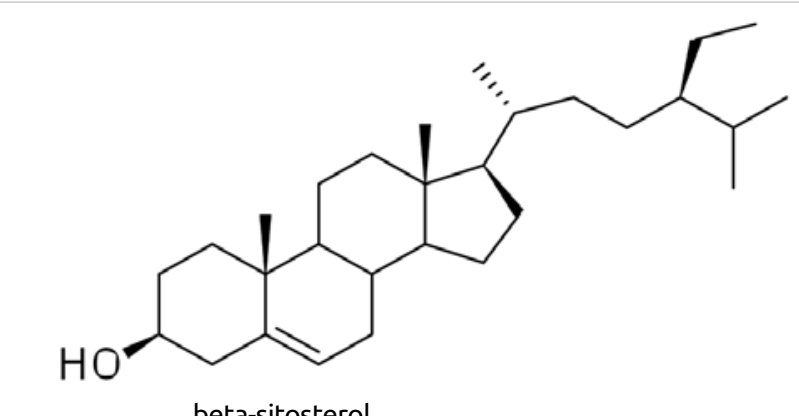

beta-sitosterol

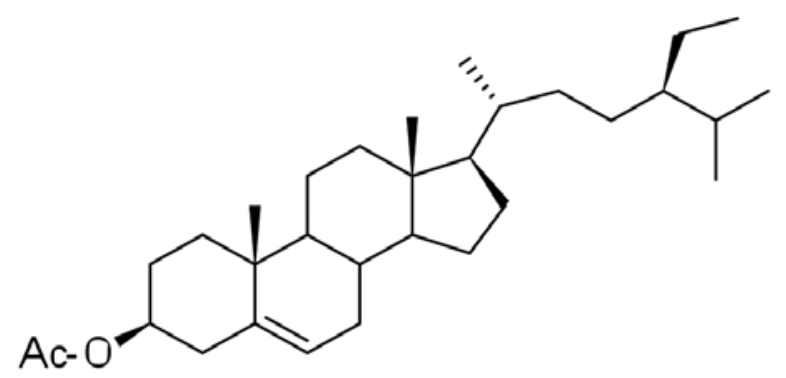

sitosterol 3-acetate

Figure 24. Structures of some triterpenoids and steroids<smiles>COc1cc2oc(-c3ccc(O)cc3)c(OC)c(=O)c2c(O)c1OC</smiles>

penduletin<smiles>COc1ccc(-c2cc(=O)c3c(O)c(OC)c(OC)cc3o2)cc1</smiles>

salvigenin

\section{Figure 25 . Structures of penduletin and salvigenin}

acid, carnosic acid 12-methyl ether, rosmadial, isorosmanol, ferruginol) (Figures 14 and 22); a labdane diterpene manool (Figure 18); four triterpenoids, oleanolic acid, ursolic acid (Figure 17), erythrodiol, and $\alpha$-amyryltetracosanoate (Figure 23); a steroid (3-acetylsitosterol) (Figure 24); and salvigenin, which is a characteristic flavone of Salvia species (Figure 25). The fatty oil of apples of the plant exhibited high anticholinesterase activity, particularly against BChE. The essential oil, consisting mainly of 1.8-cineol (58.89\%), obtained from the aerial parts of the plant, exhibited high AChE inhibitory activity (Figure 20). The antioxidant activity and anticholinesterase potential of the methanol extract and the triterpenoids $\alpha$-amyryltetracosanoate, oleanolic acid, ursolic acid, and 3-acetylsitosterol were also investigated, and the methanol ex- tract exhibited the highest antioxidant and anticholinesterase activity, surpassing those of pure compounds, probably due to synergistic effects of all components together (75).

In another study, n-butanol extract of $S$. fruticosa has shown an antiedematogenic effect on paw edema induced by carrageenan (83).

\section{Salvia lavandulifolia Vahl.}

Salvia species (S. officinalis L., S. lavandulifolia and S. miltiorrhiza Bunge) are prominent for their reputed beneficial effects on memory disorders, depression, and cerebral ischemia (69). These actions are considered to be of potential value in $\mathrm{AD}$ therapy. 
S. lavandulifolia (Spanish sage) extracts and constituents have demonstrated anticholinesterase, antioxidant, anti-inflammatory, estrogenic, and CNS-depressant (sedative) effects, relevant to the treatment of $\mathrm{AD}$. The essential oil inhibited the enzyme AChE from human brain tissue and bovine erythrocytes, and monoterpenoid constituents inhibit AChE with varying degrees of potency; particularly, 1,8-cineole (eucalyptol) (Figure 20) and a- pinene (Figure 26) showed high activity (69). Also, essential oil administration to healthy volunteers produced significant effects on cognition. In a pilot open-label study involving oral administration of the essential oil to patients with AD, a significant increase in diastolic and systolic blood pressure was observed in two patients; however, this may be attributed to pre-existing hypertension, and there were no abnormalities in other vital signs or blood samples during the trial period, and statistically significant differences were observed between baseline and 6-week treatment, with a reduction in neuropsychiatric symptoms and an improvement in attention (69).

The ability of $S$. lavandulifolia to inhibit the activity of AChE in the hippocampus is consistent with the reported memoryenhancing properties of sage. It is also of potential significance in improving cognitive function in $\mathrm{AD}$, which plays a major role in memory processing. S. lavandulifolia and $S$. officinalis have similar essential oil compositions, with the exception of the thujone content. S. officinalis oil was found to be toxic in large doses (84) due to high concentration of thujone; therefore, it is considered that $S$. lavandulifolia may be a more suitable treatment for AD (69). Also Anatolian $S$. fruticosa ( $S$. triloba) has thujone at a low percentage, which may be advantageous in use of the treatment of $\mathrm{AD}$ (75).

\section{Salvia miltiorrhiza Bunge}

S. miltiorrhiza (Chinese sage), particularly its root, which has numerous pharmacological activities, and which may be relevant in CNS disorders, including AD, has been used for the treatment of various medical conditions, including AD (30).

S. miltiorrhiza dried roots are red in color and therefore are used in Chinese folk medicine for the management of blood disorders and prescribed to stabilize the heart and calm the nerves (85). The roots also have indications to treat blood circulation disorders, insomnia, neurasthenia, and alleviation of

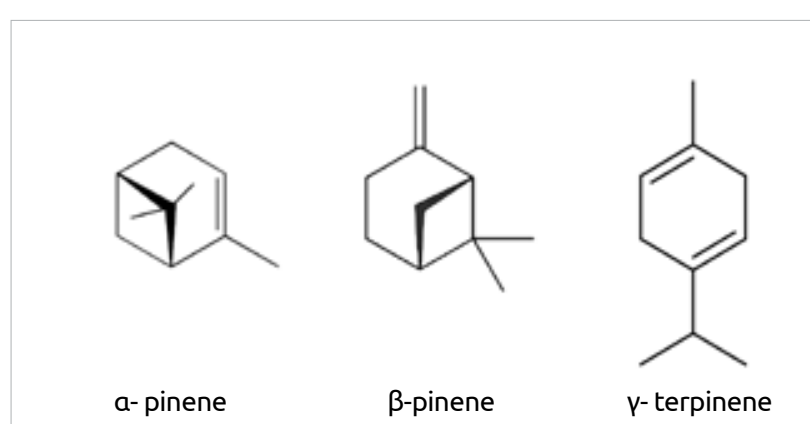

inflammation. S. miltiorrhiza has been employed for the treatment of cerebral vascular disorders and has shown benefits in some patients (86).

S. miltiorrhiza root has been implicated in decreasing dysfunction of vasoactive intestinal peptide (VIP), a neuropeptide found within the gastrointestinal tract and CNS; it may play a role in the changes that occur in cerebral ischemia (87). Thus, S. miltiorrhiza root conserves neurons from cerebral ischemia and other CNS disorders, which can be attributed to the tanshinone diterpenes as the main constituents of the root. One of the tanshinones, tanshinone IIA, the major active diterpene of $S$. miltiorrhiza, inhibited human aortic smooth muscle cell migration and MMP-9 activity, which was carried out by Jin et al. [88]. Further assessment of the relevance of Salvia species in CNS disorders is discussed by Perry and Howes (36).

S. miltiorrhiza root may offer an additional therapeutic approach to the management of stroke and ischemia. During reperfusion, metabolism of free fatty acids from the breakdown of lipid membranes in ischemia has been proposed to generate oxygen free radicals, leading to further brain injury. $S$. miltiorrhiza root has been shown to protect against this process by reducing lipid peroxidation (89).

S. miltiorrhiza roots probably inhibit neuronal cell death by inhibition of presynaptic glutamate release (87). Thus, modulation of glutamatergic activity is also recognized as a therapeutic target in $\mathrm{AD}$.

Salvianolic acid B (SalB) is a polyphenolic compound found in S. miltiorrhiza that has several anti-oxidative and anti-inflammatory effects. SalB administration significantly rescued the Ab25-35 peptide-induced decrease of choline acetyltransferase and brain-derived neurotrophic factor protein levels. These results suggest that $\mathrm{SalB}$ exerts neuroprotective activity via anti-inflammatory and anti-oxidative effects and that SalB may be a potential candidate for AD therapy (90).

The inhibition of NO formation may also explain the CNSprotective effects of S.miltiorrhiza root. Further investigations on $S$. miltiorrhiza may modify ischemic cell changes by modulating somatostatin (91).

\section{Salvia nipponica Miq. var. formosana (Hayata) Kudo}

The extracts of the roots and the leaves of Salvia nipponica var. formosana showed potent inhibitory effects on superoxide anion production in $\mathrm{fMLP} / \mathrm{CB}$-activated human neutrophils, as well as other anti-inflammatory effects. Among the isolated 25 compounds, seven of them exhibited more potent inhibitory effects on superoxide anion generation and elastase release by human neutrophils in response to fMLP/CB. Moreover, those isolated compounds also showed significant anticholinesterase and antioxidative activities (92).

\section{Salvia officinalis L.}

S. officinalis is the main medicinal Salvia species, but its native distribution is more or less restricted to the western part 
of the Balkan Peninsula (93), including Turkey. However, it is cultivated in many European and Middle Eastern countries, even all over the world. Just as mint, it is known for its soothing and carminative effects.

Pharmacological activities of sage relevant to AD include antioxidant activity, anti-inflammatory effects, and cholinesterase inhibition (94).

S. officinalis, like $S$. fruticosa, has many antioxidant compounds, particularly a diterpene carnosic acid and a stilbene rosmarinic acid with high activity. These compounds are thought to protect the brain from oxidative damage $(68,69)$.

S. officinalis is used as an herbal medicine for neuronal dysfunction. Its ability to act as an AChE inhibitor made it a natural remedy for the prevention of $\mathrm{AD}$. A clinical trial with $S$. officinalis that was given to mild and moderate $\mathrm{AD}$ patients for a period of 16 weeks showed improved cognitive performance (69).

S. officinalis extract showed potentiation of memory retention of passive avoidance learning in rats, associated with cholinergic effects and a neuroprotective effect (2). The latter effect was attributed particularly to its constituent rosmarinic acid and abietane diterpenes, also found in some other Salvia species (2). Evidence for the cognitive effects of $S$. officinalis extract has also been observed in a double-blind RCT (randomized control trial) of $\mathrm{AD}$ patients (2). In addition, it has been reported that $S$. officinalis exhibits CNS acetylcholine receptor activity, with demonstration of both nicotinic and muscarinic binding properties (87). Moreover, a recent study showed that Melissa officinalis L., another herb from this family with the same CNS acetylcholine receptor activity, modulated mood and cognitive performance in acute administration in healthy young volunteers. No side effects or symptoms of toxicity were reported with the use of $S$. officinalis (95).

One of the major active compounds of $S$. officinalis is rosmarinic acid, which has a phenolic structure and has reduced a number of events induced by AD. These include reactive oxygen species formation, lipid peroxidation, DNA fragmentation, caspase- 3 activation, and tau protein hyperphosphorylation. Moreover, rosmarinic acid inhibited phosphorylated p38 mitogen-activated protein kinase but not glycogen synthase kinase 3 activation. These data showed the neuroprotective effect of sage, which could validate the traditional use of this plant in the treatment of $\mathrm{AD}$, through one of the active ingredients, rosmarinic acid (96), which is also a main active principle of rosemary.

In a study carried out by Iuvone et al. (96), the effect of a standardized extract from the leaves of $S$. officinalis and its rosmarinic acid were evaluated for 1) cell viability, 2) oxidative stress and phosphorylated p38 (p-p38) MAP kinase activation, 3) tau protein phosphorylation, and 4) neuronal apoptosis in cultured rat pheochromocytoma (PC12) cells exposed to $A \beta$, and rosmarinic acid was found to protect PC12 cells from amyloid peptide-induced neurotoxicity.
A randomized double-blind clinical study has recently shown that an ethanolic extract from $S$. officinalis is effective in the management of mild to moderate AD (44). The clinical relevance of these findings was emphasized by the observation that the patients did not experience any adverse effect while taking sage.

\section{Salvia potentillifolia Boiss et Heldr. ex Bentham}

The essential oil of $S$. potentillifolia showed meaningful butyrylcholinesterase inhibitory activity (65.7 $\pm 0.21 \%$ inhibition), while one of the main constituents, $\alpha$-pinene, exhibited high AChE-inhibitory activity $\left(\mathrm{IC}_{50}=86.2 \pm 0.96 \mu \mathrm{M}\right)$. Antimicrobial activity was also investigated on several microorganisms, and the essential oil showed high activity against Bacillus subtilis and $B$. cereus. It also exhibited remarkable anticandidal activity against Candida albicans and C. tropicalis with MIC values of 18.5 and $15.5 \mu \mathrm{g} / \mathrm{ml}$, respectively, while the monoterpenes aand $\beta$-pinenes (Figure 26) showed moderate activity (97).

\section{Satureja species}

In Turkey, there are 15 Satureja species, five of them being endemic. Among them, S. thymbra L., S. spicigera (C. Koch) Boiss, S. cuneifolia Ten., S. boissieri Hausskn. ex Boiss, S. coerulea Janka, S. pilosa Velen., S. icarica P.H. Davis, S. wiedemanniana (Lallem.) Velen., S. hortensis L., and S. cilicica P. $H$. Davis are consumed as spices or herbal teas by the local people (98).

In a study, the essential oil of $S$. thymbra showed AChE $\left(\mathrm{IC}_{50}=150 \mu \mathrm{g} / \mathrm{mL}\right)$ - and $\mathrm{BChE}\left(\mathrm{IC}_{50}=166 \mu \mathrm{g} / \mathrm{mL}\right)$-inhibitory activities. In contrast, the methanol extract exhibited weak activity, particularly against AChE enzyme. Among the constituents of the essential oil, thymol (Figure 16) showed the best AChE- and BChE-inhibitory activities, demonstrating $\mathrm{IC}_{50}$ values of $47.5 \mu \mathrm{g} / \mathrm{mL}$ and $80.1 \mu \mathrm{g} / \mathrm{mL}$, respectively. Under the same conditions, the $\mathrm{IC}_{50}$ values of carvacrol (Figure 16) were found to be 182 and $177 \mu \mathrm{g} / \mathrm{mL}$ against $\mathrm{AChE}$ and $\mathrm{BChE}$, respectively. Other monoterpenes, such as $\gamma$-terpinene (Figure 26), however, exhibited nearly the same activity as that of carvacrol against AChE enzyme $\left(\mathrm{IC}_{50}=181 \mu \mathrm{g} / \mathrm{mL}\right)$ and very close activity to that of thymol (Figure 16) against BChE enzyme ( $\left(\mathrm{IC}_{50}=85.8 \mu \mathrm{g} / \mathrm{mL}\right)(99)$.

\section{Scutellaria species}

The members of Scutellaria (Lamiaceae) are known to be rich, particularly in flavonoids. Among Scutellaria species, S. baicalensis Georgi, a famous Chinese medicinal plant, has been prescribed for treatment of memory deficit in traditional Chinese medicine. To date, there have been a number of studies performed on S. baicalensis and their constituents for their memory-enhancing effects. The ethanol extract of the roots of S. baicalensis of Korean origin was shown to possess neuroprotective effects, tested by passive avoidance test in ibotenic acid-induced amnesia in rats. In a study, methanol extracts of the aerial parts of 33 Turkish Scutellaria species were screened for their anticholinesterase activity, and all extracts exhibited only weak $\mathrm{AChE}$ and $\mathrm{BChE}$ inhibition, indicating that the 
memory-enhancing property of Scutellaria species may not result from $\mathrm{AChE}$ and/or BChE inhibition but by some other mechanisms, as suggested in different reports (100).

\section{Sideritis Species}

Sideritis species are very popular and marketed as mountain tea, plateau tea, malotira, te'de Puerto, and dag cayi in Turkey. Plants of the genus Sideritis are widely used in folk medicine in the Mediterranean region. The decoction and/ or the infusion of aerial parts is traditionally used as an antimicrobial, anti-inflammatory, antiulcerative, anticonvulsant, antispasmodic, and carminative agent (101).

One of our recent studies on Sideritis species, S. arguta Boiss et Heldr. (Figure 27) extracts, and pure ent-kaurene diterpenes (Figure 28) has come into focus due to the observed inhibitory effects on both cholinesterase enzymes in vitro (102).

The extracts of S. congesta P. H. Davis \& Hub.-Mor. and its eight isolated diterpenes with an ent-kaurane structure were investigated for antioxidant potential by three methods, including beta-carotene bleaching method, DPPH free radicalscavenging activity, and superoxide anion-scavenging activity. The anticholinesterase activity was also evaluated for the entkauranes, and most of the diterpenes exhibited weak AChE inhibitory activity. However, almost all diterpenes exhibited some inhibitory activity against BChE enzyme; particularly sideroxol and 7-epicandicandiol (Figure 28) exhibited better BChE-inhibitory activity than the drug galantamine (103).

Aqueous and alcoholic extracts of S. scardica Griseb. (Figure 25) have turned out to act as triple monoamine reuptake inhibitors in the phytochemical therapy of mental disorders with neurodegenerative disorders (104).
The AChE and BChE inhibitory activities of the acetone, methanol, and water extracts of $S$. caesarea Duman, Aytac \& Baser and the flavones penduletin and apigenin were evaluated at $200 \mu \mathrm{g} / \mathrm{mL}$, and penduletin (Figure 25) exhibited significant activity against $\mathrm{BChE}(66.58 \%)$, while apigenin showed weak activity against both enzymes (105).

\section{Stachys lavandulifolia Vahl.}

More than 270 plant species constitute the genus Stachys, which is one of the largest genera of the mint family, Labiatae.

The hydroalcoholic extract of the aerial parts of S. lavadulifolia posseses sedative and anxiolytic activities in mice, based on spontaneous motor activity and elevated plus maze assays; petroleum ether, ethyl acetate, and water fractions also showed

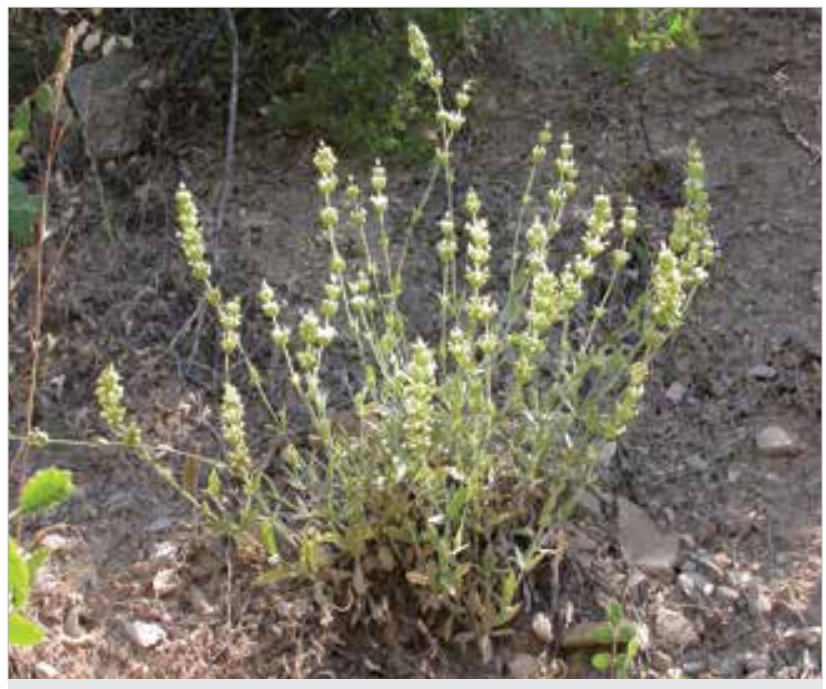

Figure 27. Sideritis arguta Boiss. et Heldr.

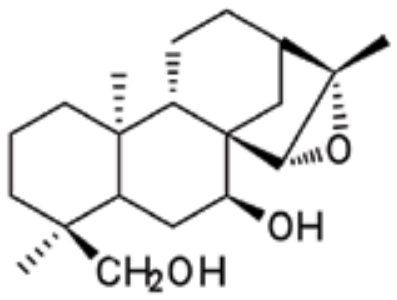

sideroxol

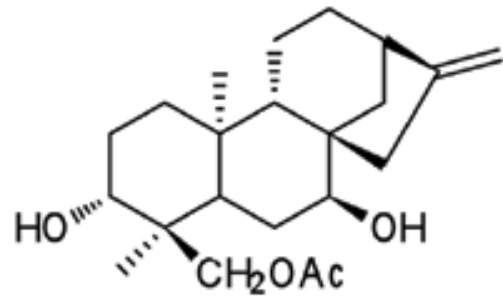

linearol

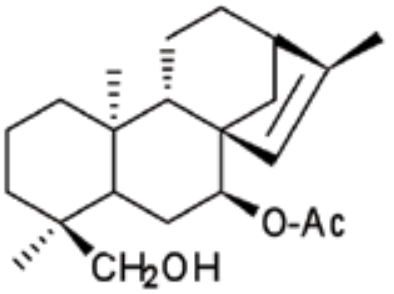

siderol

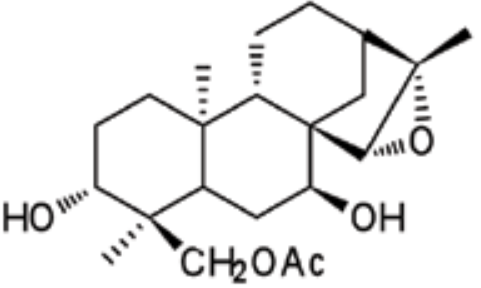

epoxyisolinearol

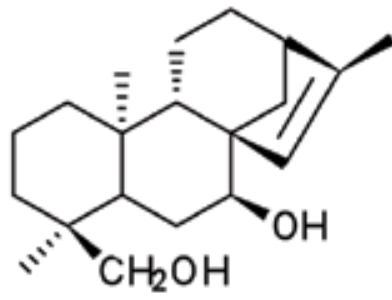

sideridiol

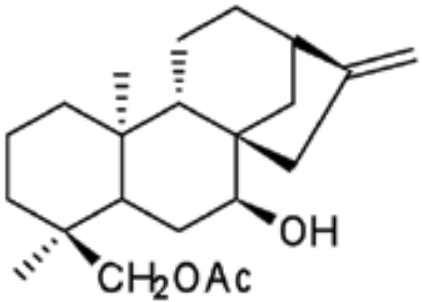

7-epicandicandiol 
anxiolytic activity in mice (106). Therefore, this plant has great potential as a source for natural health products.

A study suggested that $S$. byzantina $\mathrm{K}$. Koch has strong antioxidant activity (107).

\section{Thymus species}

The genus Thymus (known as kekik in Turkey) is widely distributed in the Mediterranean region, with a characteristic aroma and great value as culinary herbs, ornamental plants, and flavoring agents (108). In addition, these plants possess an array of biological properties that positively impact human health (109).

The genus Thymus is represented by 41 species in Turkey, and 24 of them are endemic. Amongst them, Thymus praecox Opiz subsp. caucasicus (Ronniger) Jalas var. caucasicus (Ronniger) Jalas is consumed as "Anzer tea" in Anatolia (110).

The extracts of T. lotocephalus, obtained by SFE (super critical fluid extraction) method, exhibited high anticholinesterase activity, with $\mathrm{IC}_{50}$ values of $1.54 \pm 0.04$ and $0.14 \pm 0.02 \mu \mathrm{g} /$ $\mathrm{mL}$ against $\mathrm{AChE}$ and $\mathrm{BChE}$, respectively. The essential oil of $T$. lotocephalus also strongly inhibited cholinesterases, with $\mathrm{IC}_{50}$ values of $0.90 \pm 0.04$ and $0.50 \pm 0.12 \mu \mathrm{g} / \mathrm{mL}$ against $\mathrm{AChE}$ and $\mathrm{BChE}$, respectively. This effect might be attributed to its major constituents, 1,8-cineole (eucalyptol) (Figure 20) and caryophyllene oxide (Figure 21) (109).

Anti-inflammatory properties of the essential oil of T. vulgaris L. were shown through its ability to repress the enzymatic activity of 5-lipoxygenase and to reduce the secretion of the pro-inflammatory cytokines TNF-, IL-1, and IL-8 in THP-1 cells, which may contribute to its potential anti-Alzheimer effect. Furthermore, the T. vulgaris essential oil, which possesses a high percentage of thymol, exhibited the highest antioxidant activity (111).

The anti-inflammatory effect of T. kotschyanus Boiss. extract on rat hind paw edema has been induced by carrageenan (112).

Based on epidemiological evidence, various environmental toxins, including pesticides, may have a role in the etiology of idiopathic neurodegenerative diseases (113). The antioxidant effects of a series of plant extracts and/or their bioactive components against neurotoxicity induced by pesticides (paraquat and rotenone) using the Drosophila model system were presented in a recent study, indicating that the fruit fly (Drosophila melanogaster) can be used for early-stage drug discovery and development for identification of novel plantderived compounds to protect against neurodegeneration in $\mathrm{AD}$ and Parkinson's disease and other neurological disorders caused by oxidative stress (114).

\section{Conclusion}

One of the most active phytochemical products from the Lamiaceae family plants is rosmarinic acid, which displays a number of mechanistic effects relevant to dementia. Some Lamiaceae plants, particularly rosemary (Rosmarinus), sage (Salvia), lemon balm (Melissa officinalis), catmint (Nepeta), and lavender (Lavandula), are rich in rosmarinic acid and other phenolics that have strong antioxidant, anti-inflammatory, and neuroprotective effects in the treatment of neurological disorders, particularly $\mathrm{AD}$ [2]. As terpenoids, triterpenoids, especially oleane, ursane, and lupane triterpenoids, have high potential in the treatment of $\mathrm{AD}$ in the future. Ursolic/oleanolic acid or betulinic acid and their derivatives are important potential agents in the treatment of $\mathrm{AD}$ and maybe in other neurodegenerative diseases with dementia.

Diterpenes, especially phenolic ring-containing diterpenes, such as abietanes, were tested for anticholinesterase activity, and most abietanes have been found to be active against $\mathrm{BChE}$ particularly rather than $\mathrm{AChE}(75,79,92)$. Ferruginol and taxodione are fairly common abietanes isolated from a number of Salvia species that exhibited high BChE inhibition activity and weak-moderate AChE inhibition activity, indicating their dual inhibition properties. Several abietane diterpenoids, including carnosol and carnosic acid, and quinoid abietanes, such as tanshinones, should also be considered potential anti-Alzheimer agents.

Essential oils of Satureja, Thymus, Origanum, and Thymbra (all called kekik in Turkey) species are known to be rich in the monoterpenes thymol and carvacrol as well as $\beta$-pinene. Volatile constituents of the essential oils are likely to readily cross the blood-brain barrier due to their small molecular size and lipophilicity. Their volatile nature may also enable their administration as an inhaled vapor (115). Therefore, consumption of Lamiaceae plants rich in thymol and carvacrol is useful in the treatment of $\mathrm{AD}(99)$.

According to the results above, nonpolar extracts of the Lamiaceae family plants for anticholinesterase activity and the polar extracts for antioxidant activity are found to be effective and complement each other. From Anatolian Salvia species, triterpenic acids (oleanolic and ursolic acids) have been isolated in huge amounts (range $0.01-0.1 \%$ yield) in general, even at a higher yield in some species $(1 \%)$, especially from aerial parts of the plants. Abietane diterpenes were also isolated from Salvia species in high yield but especially from their roots. The triterpenes isolated were found to be responsible for AChE inhibition, while diterpenes were found to be responsible for $\mathrm{BChE}$ inhibition, in general. As a conclusion, a number of Lamiaceae plants that have been investigated might be considered as potential anticholinesterase agents in the treatment of $\mathrm{AD}$ with dual inhibition on $\mathrm{AChE}$ and $\mathrm{BChE}$, which requires immediate clinical trials.

Peer-review: Externally peer-reviewed.

Author Contributions: Concept - G.T.; Design - T.K.; Supervision G.T.; Funding - G.T.; Analysis and/or Interpretation - G.T.; Literature Review - T.K.; Writing - G.T.; Critical Review - G.T.; Other - T.K. 
Acknowledgements: The authors would like to thank the Scientific and Technological Research Council of Turkey (TUBITAK) to support this study with a project TBAG-107T592.

Conflict of Interest: No conflict of interest was declared by the authors.

Financial Disclosure: The authors declared that this study has received no financial support.

Hakem değerlendirmesi: Dış bağımsız.

Yazar Katkıları: Fikir - G.T.; Tasarım - T.K.; Denetleme - G.T.; Kaynaklar - G.T.; Analiz ve/veya yorum - G.T.; Literatür taraması - T.K.; Yazıyı yazan - G.T.; Eleştirel İnceleme - G.T.; Diğer - T.K

Teşekkür: Yazarlar TBAG-107T592 projesi ile bu çalışmaya destek veren Türkiye Bilimsel ve Teknolojik Araştırma Kurumu'na (TUBITAK) teşekkür eder.

Çıkar Çatışması: Yazarlar çıkar çatışması bildirmemişlerdir.

Finansal Destek: Yazarlar bu çalışma için finansal destek almadıklarını beyan etmişlerdir.

\section{References}

1. Huang L, Su T, Li X. Natural Products as Sources of New Lead Compounds for the Treatment of Alzheimer's disease. Curr. Top. Med. Chem 2013; 13: 1864-78. [CrossRef]

2. Howes MJR, Perry E. The Role of Phytochemicals in the Treatment and Prevention of Dementia. Drug \& Aging 2011; 28: 439-68. [CrossRef]

3. Greig NH. Lahiri DK. Sambamurti K. Butyrylcholinesterase: An important new target in Alzheimer's disease therapy. Int. Psychoger 2002; 14: 77-91. [CrossRef]

4. Williams P, Sorribas A, Howes MJ. Natural products as a source of Alzheimer's drug leads. Nat Prod Rep 2011; 28: 48-77. [CrossRef]

5. Mangialasche F, Solomon A, Kareholt I, Hooshmand B, Cecchetti $\mathrm{R}$, Fratiglioni L, et al. Serum levels of vitamin E forms and risk of cognitive impairment in a Finnish cohort of older adults. Exp. Geront 2013; 48: 1428-35. [CrossRef]

6. Ansari N, Khodagholi F. Natural Products as Promising Drug Candidates for the Treatment of Alzheimer's disease: Molecular Mechanism Aspect. Curr. Neuropharm 2013; 11: 414-29. [CrossRef]

7. Arlington, VA, "Diagnostic and Statistical Manual of Mental Disorders, Fourth Edition, Text Revision USA: Am. Psych. Pub. Inc, 2000.pp.526-9.

8. Singhal AK, Naithani V, Bangar OP. Medicinal plants with a potential to treat Alzheimer and associated symptoms. Int. J. Nutr. Pharm. Neur. Dis 2012; 2: 84-91. [CrossRef]

9. Wright CI, Geula C, Mesulam MM. Neurological choline-esterases in the normal brain and in Alzheimer's disease: relationship to plaques, tangles and patterns of selective vulnerability. Ann. Neurol 1993; 34: 373-84. [CrossRef]

10. Giacobini E. Selective inhibitors of butyrylcholinesterase: A valid alternative for therapy of Alzheimer's disease? Drug Aging 2001; 18: 891-8. [CrossRef]

11. Jayaprakasam B, Padmanabhan K, Nair MG. Withanamides in Withania somnifera fruit protect PC-12 cells from beta-amyloid responsible for Alzheimer's disease. Phytother. Res 2010; 24: 859-63.

12. Yoo KY, Park SY. Terpenoids as potential Anti-Alzheimer's disease Therapeutics. Molecules 2012; 17: 3524-38. [CrossRef]

13. Murray AP, Faraoni MB, Castro MJ, Alza NP and Cavallaro V. Natural AChE Inhibitors from Plants and their Contribution to Alzheimer's disease Therapy. Curr. Neuropharm 2013; 11: 388-413. [CrossRef]
14. Palmer AM. Pharmacotherapy for Alzheimer's disease: progress and prospects. Trends in Pharm. Sci 2002; 23: 426-33.

15. Lockhart IA, Mitchell SA, Kelly S. Safety and tolerability of donepezil, rivastigmine and galantamine for patients with Alzheimer's disease: systematic review of the 'real world' evidence. Dement. Geriatr. Cogn 2009; 28: 389-403. [CrossRef]

16. Leonard AK, Sileno AP, Macevilly C, Foerder CA, Quay SC, Costantino HR. Development of a novel high-concentration galantamine formulation suitable for intranasal delivery. J. Pharm. Sci 2005; 94: 1736-46. [CrossRef]

17. McNulty J, Nair JJ, Little JRL, Brennan JD, Bastida J. Structureactivity studies on acetylcholinesterase inhibition in the lycorine series of Amaryllidaceae alkaloids. Bioorg Med Chem Lett 2010; 20: 5290-4. [CrossRef]

18. Pinho BR, Ferreres F, Valentao P, Andrade PB. Nature as a source of metabolites with cholinesterase-inhibitory activity: an approach to Alzheimer's disease treatment. J. Pharm. Pharmacolog 2013; 65; 1681-700. [CrossRef]

19. Thal LJ, Ferguson JM, Mintzer J, Raskin, A, Targum, SD. A 24week randomized trial of controlled release physostigmine (5) in patients with Alzheimer's disease. Neurology 1999; 52: 1146-52. [CrossRef]

20. Coelho F, Birks J. Physostigmine for Alzheimer's disease. Cochrane Database Syst. Rev 2001; 2: CD001499.

21. Braida D, Sala M. Eptastigmine: ten years of pharmacology, toxicology, pharmacokinetic, and clinical studies. CNS Drug Rev 2001; 7: 369-86. [CrossRef]

22. Kamal MA, Klein P, Yu QS, Tweedie D, Li Y, Holloway HW, et al. Kinetics of human serum butyrylcholinesterase and its inhibition by a novel experimental Alzheimer therapeutic, bisnorcymserine. J Alzheimer's Dis 2006; 10: 43-51.

23. Butler MS. Natural products to drugs: natural product derived compounds in clinical trials. Nat. Prod. Rep 2008; 25: 475-516. [CrossRef]

24. R.Ron Finley, B.S Pharm, R.Ph,CGP, Aimee Loucks, Pharm. D., Gil D. Rabinovici, M.D. Medications Used for The Management of Dementia and Related Behaviorial Complications. Alzheimer Association. 2012.

25. Howes MJ, Perry NS, Houghton PJ. Plants with traditional uses and activities, relevant to the management of Alzheimer's disease and other cognitive disorders. J. Pharmacol. Exp. Ther 2003; 17: 1-18.

26. Howes MJR, Houghton PJ. Plants used in Chinese and Indian traditional medicine for improvement of memory and cognitive function. Pharmacol. Biochem. Be 2003; 75: 513-27. [CrossRef]

27. http://www.kew.org/science/lampubs.html Kew Royal Botanic Gardens.

28. Madsen HL, Bertelsen G. Spices as Antioxidants, Trends in Food Sci. \& Tech 1995; 6: 271-7.

29. Ulubelen A, Topçu G, and Kolak U. "Studies in Natural Product Chemistry", Labiatae Flavonoids and Their Bioactivity (Ed) Attaur-Rahman Elsevier, Amsterdam, 2005; 30: 233-302.

30. Perry E, Howes M-JR. Medicinal plants and dementia therapy: Herbal hopes for brain aging? CNS Neurosci. Ther 2011; 17: 68398. [CrossRef]

31. Tuncer H. Utilization of Wild Plants as Medicine, vol. II the ministry of food and agriculture Atak Printhouse, Ankara-Turkey, 1978.

32. Baytop T. Therapy with Medicinal Plants in Turkey ( $2^{\text {nd }}$ ed.). Istanbul: Nobel Tip Publication Press; 1999.p.332.

33. LaGow B, Gruenwald J, Brendler T, Jaenicke C. PDR for Herbal Medicines, $3^{\text {rd }}$ ed. Thomson, Herbal Monographs, Cornell University, USA, 2004. pp. 485-8.

34. Rahmati B, Khalili M, Roghani M, Ahghari P. Anti-epileptogenic and antioxidant effect of Lavandula officinalis aerial part extract 
against pentylenetetrazol-induced kindling in male mice. J. Ethnopharm 2013; 148: 152-7. [CrossRef]

35. Zuzarte M, Gonçalvesa MJ, Cavaleiroa C, Cruzb MT, Benzartic A, Marongiud B, et al. Antifungal and anti-inflammatory potential of Lavandula stoechas and Thymus herba-barona essential oils. Ind. Crop. Prod 2013; 44: 97-103. [CrossRef]

36. Topçu G, Ayral MN, Aydin A, Gören AC, Chai HB, Pezzuto JM. Triterpenoids of the roots of Lavandula stoechas ssp stoechas, Pharmazie 2001; 56; 892-5.

37. Hancianu M, Cioanca O, Mihasan M, Hritcu L. Neuroprotective effects of inhaled lavender oil on scopolamine-induced dementia via antioxidative activities in rats. Phytomedicine 2013; 20: 446-52. [CrossRef]

38. AdsersenA, Gauguin B, Gudiksen L, JagerAK.Screeningofplantsused in Danish folk medicine to treat memory dysfunction for acetylcholinesterase inhibitory activity. J. Ethnopharmacol 2006; 104: 418-22. [CrossRef]

39. Hung TM, Luan TC, Vinh BT, Cuong TD, Min BS. Labdane-type Diterpenoids from Leonurus heterophyllus and Their Cholinesterase Inhibitory Activity. Phytother. Res 2011; 25: 611-4. [CrossRef]

40. Bağdat RB, Coşge B. The Essential Oil of Lemon Balm (Melissa officinalis L.), Its Components and Using Fields. J. Fac. Agric. OMU 2006; 21: 116-21.

41. Akhondzadeh S, Nooroonzian M, Mohammadi M, Ohadinia S, Jamshidi AH, Khani M. Melissa officinalis extract in the treatment of patient with mild to moderate Alzheimer's disease: A double blind, randomised, placebo controlled trial. Food Prot. Apr 2003; 6: 625-32.

42. Kennedy DO, Little W, Scoley AB. Attenuation of laboratoryinduced stres in humans after acute administration of Melissa officinalis (lemon balm). J. Pharm. Pharmacol 2004; 56: 677-81.

43. Bolkent S, Yanardağ R, Karabulut-Bulan O, Yeşilyaprak B. Protective role of Melissa officinalis L. extract on liver of hyperlipidemic rats: A morphological and biochemical study. Ethnopharmacol 2005; 99: 391-8. [CrossRef]

44. Kennedy DO, Scholey AB. The psychopharmacology of European herbs with cognition-enhancing properties. Curr. Pharm. Des 2006; 12: 4613-23. [CrossRef]

45. Lopez V, Martin S, Gomez-Serranillos MP, Carretero ME, Jager AK, Calvo MI. Neuroprotective and Neurological Properties of Melissa officinalis. Neurochem. Res 2009; 34: 1955-61. [CrossRef]

46. Muzell DP, Lunardelli A, Leite CE, Fagundes RM, Saciura VC, Reichel CL, et al. Nephroprotective and Anti-inflammatory Effects of Aqueous Extract of Melissa officinalis L. on Acetaminopheninduced and Pleurisy-induced Lesions in Rats. Braz. Arch. Biol. Techn 2013; 56: 383-92. [CrossRef]

47. Birdane YO, Buyukokuroglu ME, Birdane FM, Cemek M, Yavuz H. Anti-inflammatory and antinociceptive effects of Melissa officinalis L. in rodents. Rev. Med. Vet-Toulouse 2007; 158: 75-81.

48. Öztürk M, Kolak U, Topçu G, Öksüz S, Choudhary I. Antioxidant and anticholinesterase active constituents from Micromeria cilicica by radical-scavenging activity-guided fractionation. Food Chem 2011; 126: 31-8. [CrossRef]

49. Öztürk M, Kolak U, Duru ME, Harmandar M.GC-MS Analysis of the Antioxidant Active Fractions of Micromeria juliana with Anticholinesterase Activity. Nat. Prod. Commun 2009; 4: 1271-6.

50. Yılmaz A, Çağlar P, Dirmenci T, Gören N, Topçu G. A Novel Isopimarane Diterpenoid with Acetylcholinesterase Inhibitory Activity from Nepeta sorgerae, an Endemic Species to the Nemrut Mountain. Nat. Prod. Commun 2012; 7: 693-6.

51. Topçu G, Kökdil G, Yalçın SM. Constituents of Nepeta caesarea. J. Nat. Prod 2000; 63: 888-90. [CrossRef]

52. Başer KHC. The Turkish Origanum species, in: Kintzios SE, ed., Oregano, The Genera Origanum and Lippia. London, Taylor and Francis; 2002.pp.109-26.
53. Loizzo MR, Menichini F, Conforti F, Tundis R, Bonesi M, Saab AM, et al. Chemical analysis, antioxidant, antiinflammatory and anticholinesterase activities of Origanum ehrenbergii Boiss and Origanum syriacum L. essential oils. Food Chem 2009; 117: 174-80. [CrossRef]

54. Mossa AT, Nawwar GA. Free radical scavenging and antiacetylcholinesterase activities of Origanum majorana L. essential oil. Hum. Exp. Toxicol 2011; 30: 1501-13. [CrossRef]

55. CESA. Usos tradicionales de las especies forestales nativas en el ecuador. Tomo III, 1993.pp. 274.

56. Choi S, Hur JM, Yang EJ, Jun M, Park HJ, Lee KB, et al. BetaSecretase (BACE1) Inhibitors from Perilla frutescens var. acuta. Arch. Pharm. Res 2008; 31: 183-7. [CrossRef]

57. Orhan İ, Aslan S, Kartal M, Şener B, Başer KHC. Inhibitory effect of Turkish Rosmarinus officinalis L. on acetylcholinesterase and butyrylcholinesterase enzymes. Food Chem 2008; 108: 663-8. [CrossRef]

58. Fregozo CS, Beltran MLM, Soto MEF, Vega MIP, Zarate CB, Ruiz LH. Expression of NMDA receptor subunits in rat prefrontal cortex with CCl4-induced hepatic damage after a treatment with Rosmarinus officinalis L. Neurologia 2012; 27: 261-7. [CrossRef]

59. Park SE, Kim S, Sapkota K, Kim SJ. Neuroprotective Effect of Rosmarinus officinalis Extract on Human Dopaminergic Cell line, SH-SY5Y. Cell. Mol. Neurobiol 2010; 30: 759-67. [CrossRef]

60. Omri AEL, Han J, Ben Abdrabbah M, Isoda H. Down regulation effect of Rosmarinus officinalis polyphenols on cellular stress proteins in rat pheochromocytoma PC12 cells. Cytotechnology 2012; 64: 231-40. [CrossRef]

61. Tamaki Y, Tabuchi T, Takahashi T, Kosaka K, Satoh T. Activated Glutathione Metabolism Participates in Protective Effects of Carnosic Acid against Oxidative Stress in Neuronal HT22 Cells. Planta Med 2010; 76: 683-8. [CrossRef]

62. Kayashima T, Matsubara K. Antiangiogenic Effect of Carnosic Acid and Carnosol, Neuroprotective Compounds in Rosemary Leaves. Biosci. Biotech. Bioch 2012; 76: 115-9. [CrossRef]

63. Satoh T, Kosaka K, Itoh K, Kobayashi A, Yamamoto M, Shimojo $\mathrm{Y}$, et al. Carnosic acid, a catechol-type electrophilic compound, protects neurons both in vitro and in vivo through activation of the Keap1/Nrf2 pathway via S-alkylation of targeted cysteines on Keap1. J. Neurochem 2008; 104: 1116-31. [CrossRef]

64. Zanella CA, Treichel H, Cansian RL, Roman SS. The effects of acute administration of the hydroalcoholic extract of rosemary (Rosmarinus officinalis L.) (Lamiaceae) in animal models of memory. Braz. J. Pharm. Sci. 48: 389-97.

65. Duke JA. The Garden Pharmacy: Rosemary, the Herb of Remembrance for Alzheimer's disease. Alternat. Complement. Ther 2007; 13: 287-90. [CrossRef]

66. Walker JB, Sytsma K, Treutlein J, Wink M. Salvia (Lamiaceae) is not monophyletic: implications for the systematics, radiation, and ecological specializations of Salvia and tribe Menthae. Am. J. Bot 2004; 91: 1115-25. [CrossRef]

67. Topçu G. Bioactive triterpenoids from Salvia species. J. Nat. Prod 2006; 62: 482-7. [CrossRef]

68. Wu YB, Ni ZY, Shi QW, Dong M, Kiyota H, Gu YC, et al. Constituents from Salvia Species and Their Biological Activities. Chem. Rev 2012; 112: 5967-6026. [CrossRef]

69. Perry NSL, Bollen C, Perry EK, Ballard C. Salvia for dementia therapy: review of pharmacological activity and pilot tolerability clinical trial. Pharmacol. Biochem. Behav 2003; 75: 651-9. [CrossRef]

70. Orhan I, Kartal M, Naz Q, Ejaz A, Yılmaz G, Kan Y, Konuklugil B, Şener B, Choudhary MI. Antioxidant and anticholinesterase evaluation of selected Turkish Salvia species. Food Chem 2007; 103: 1247-54. [CrossRef]

71. Silva I, Mor G, Naftolin F. Estrogen and the aging brain. Maturitas 2001; 38: 95-101. [CrossRef] 
72. Tyler VE. Phytomedicines in Western Europe: potential impact on herbal medicine in the United States. Human medicinal agents from plants. Am Chem Soc 1993; 25-37.

73. Şenol FS, Orhan IE, Erdem SA, Kartal M, Şener B, Kan Y, et al. Evaluation of cholinesterase inhibitory and antioxidant activities of wild and cultivated samples of Sage (Salvia fruticosa) by activityguided fractionation. J. Med. Food 2011; 14: 1476-83. [CrossRef]

74. Perry NSL, Houghton PJ, Sampson J, Theobald AE, Hart S, LisBalchin $\mathrm{M}$, et al. In vitro activities of S. lavandulaefolia (Spanish sage) relevant to treatment of Alzheimers disease. J. Pharm. Pharmacol 2001; 53: 1347-56. [CrossRef]

75. Topçu G, Öztürk M, Kuşman T, Barla Demirkoz AA, Kolak U, Ulubelen A. Terpenoids, essential oil composition and fatty acids profile, and biological activities of Anatolian Salvia fruticosa Mill. Turk. J. Chem 2013; 37: 619-32.

76. Ren YH, Houghton PJ, Hider RC, Howes MJ. Novel diterpenoid acetylcholinesterase inhibitors from Salvia miltiorhiza. Planta Med. 2004; 70: 201-204. [CrossRef]

77. Topçu G, Kolak U, Öztürk M, Boğa M, Hatipoğlu SD, Bahadori F, Çulhaoğlu B, Dirmenci T. Investigation of Anticholinesterase Activity of a Series of Salvia Extracts and the Constituents of Salvia staminea. Nat Prod J 2013; 3: 3-9.

78. Tel G, Öztürk M, Duru; ME, Harmandar, M, Topçu G. Chemical composition of the essential oil and hexane extract of Salvia chionantha and their antioxidant and anticholinesterase activities. Food Chem. Toxicol 2010; 48: 3189-93. [CrossRef]

79. Çulhaoğlu B, Yapar G, Dirmenci T, Topçu G. Bioactive constituents of Salvia chrysophylla Stapf. Nat Prod Res 2013; 27: 438-47. [CrossRef]

80. Dimas K, Demetzos C, Vaos, V, Ioannidis P, Trangas T. Labdane type diterpenes down-regulate the expression of c-myc protein, but not bcl-2, in human leukemia T-cells undergoing apoptosis. Leukemia Res 2001; 25: 449-54. [CrossRef]

81. Salah SM, Jager AK. Screening of traditionally used Lebanese herbs for neurological activities. J. Ethnopharmacol 2005; 97: 145-9. [CrossRef]

82. Orhan I, Aslan M. Appraisal of scopolamine-induced antiamnesic effect in mice and in vitro antiacetylcholinesterase and antioxidant activities of some traditionally used Lamiaceae plants. J. Ethnopharmacol 2009; 122: 327-32. [CrossRef]

83. Cadirci E, Suleyman H, Gurbuz P, Kuruuzum UZA, Guvenalp Z, Demirezer LO. Anti-inflammatory effects of different extracts from three Salvia species. Turk J Biol 2012; 36: 59-64.

84. Perry NB, Baxter AJ, Brennan NJ, Klink JW. Dalmatian sage. Part 1. Differing oil yields and compositions from flowering and nonflowering accessions. Flavour Frag J 1996; 11: 231-8. [CrossRef]

85. Huang KC. The pharmacology of Chinese herbs. Boca Raton (FL): CRC Press. 1993

86. Chang H, But PP. Pharmacology and applications of Chinese materia medica, vol. 1-2. Singapore: World Scientific; 2001.

87. Kuang P, Wu W, Zhang F, Liu J, Pu C. The effect of Radix Salviae Miltiorrhizae on vasoactive intestinal peptide in cerebral ischaemia: an animal experiment. J. Tradit. Chin. Med 1989; 9: 203-6.

88. Jin UH, Suh SJ, Chang HW, Son JK, Lee SH, Son KH, et al. Tanshinone IIA From Salvia miltiorrhiza Bunge inhibits Human Aortic Smooth Muscle Cell Migration and MMP-9 Activity Through AKT Signaling Pathway, J. Cell. Biochem 2008; 104: 15-26. [CrossRef]

89. Liu G, Zhang T, Wang B, Wang Y. Protective action of seven natural phenolic compounds against peroxidative damage to biomembranes. Biochem. Pharmacol 1992; 43: 147-52. [CrossRef]

90. Lee YW1, Kim DH, Jeon SJ, Park SJ, Kim JM, Jung JM, et al. Neuroprotective effects of salvianolic acid B on an A beta (25-35) peptide-induced mouse model of Alzheimer's disease. Eur. J. Pharmacol. 2013; 704: 70-77. [CrossRef]

91. Kuang P, Wu W, Zhu K. Evidence for amelioration of cellular damage in ischemic rat brain by Radix Salviae Miltiorrhizae treatmentimmuno-chemistry and histopathology studies. J. Tradit. Chin. Med 1993; 13: 38-41.

92. Chan HH, Hwang TL, Su CR, Reddy MVB, Wu TS Anti-inflammatory, anticholinesterase and antioxidative constituents from the roots and the leaves of Salvia nipponica Miq. var. formosana, Phytomedicine 2011; 18: 148-50. [CrossRef]

93. Ulubelen, A. "Terpenoids of the Genus" in SAGE The Genus Salvia, Spiridon E. Knitzios, Ed.; Harwood Academic Publishers, Amsterdam, 2000: 55-68.

94. Baricevic D, Sosa S, Della Loggia R, Tubaro A, Simonovska B, Krasna A, et al. Topical anti-inflammatory activity of Salvia officinalis L. leaves: the relevance of ursolic acid. J. Ethnopharmacol 2001; 75: 125-32. [CrossRef]

95. Wake G, Court J, Pikering A, Lewis R, Wilkins R, Perry E. CNS acetylcholine receptor activity in European medicinal plants traditionally used to improve failing memory. J. Ethnopharmacol 2000; 69: 105-14. [CrossRef]

96. Iuvone T, De Filippis D, Esposito G, D’Amico A, Izzo AA. The spice sage and its active ingredient rosmarinic acid protect PC12 cells from amyloid-peptide-induced neurotoxicity. J. Pharmacol. Exp. Ther 2006; 317: 1143-9. [CrossRef]

97. Kivrak I, Duru ME, Ozturk M, Mercan N, Harmandar M, Topçu G. Antioxidant, anticholinesterase and antimicrobial constituents from the essential oil and ethanol extract of Salvia potentillifolia. Food Chem 2009; 116: 470-9. [CrossRef]

98. Satil F, Dirmenci T, Tümen G, Turan Y. Commercial and ethnic uses of Satureja (Sivri Kekik) species in Turkey. Ekoloji 2008; 67: 1-7. [CrossRef]

99. Öztürk M. Anticholinesterase and antioxidant activities of Savoury (Satureja thymbra L.) with identified major terpenes of the essential oil. Food Chem 2012; 134: 48-54. [CrossRef]

100. Şenol FS, Orhan I, Yılmaz G, Çicek M, Şener B. Acetylcholinesterase, butyrylcholinesterase, and tyrosinase inhibition studies and antioxidant activities of 33 Scutellaria L. taxa from Turkey. Food Chem. Toxicol 2010; 48: 781-8. [CrossRef]

101. Gonzalez-Burgos E, Carretero ME, Gomez-Serranillos MP. Sideritis spp.: uses, chemical composition and pharmacological activitiesa review. J. Ethnopharmacol 2011; 135: 209-25. [CrossRef]

102. Ertaş A, Öztürk M, Boğa M, Topçu G. Antioxidant and anticholinesterase activity evaluation of ent-kaurane diterpenoids from Sideritis arguta. J. Nat. Prod 2009; 72: 500-2. [CrossRef]

103. Topçu G, Ertaş A, Öztürk M Dincel D, Kılıc T Halfon B. Entkaurane diterpenoids isolated from Sideritis congesta. Phytochem. Lett 2011; 4: 436-9. [CrossRef]

104. Knörle R. Extracts of Sideritis scardica as triple monoamine reuptake inhibitors. J. Neural. Transm 2012; 119: 1477-82. [CrossRef]

105. Halfon B, Ciftci E, Topçu G. Flavonoid constituents of Sideritis caesarea. Turk J Chem 2013; 37: 464-72.

106. Rabbani M, Sajjadi SE, Zarei HR. Anxiolytic effects of Stachys lavandulifolia Vahl on the elevated plus-maze model of anxiety in mice. J. Ethnopharmacol 2003; 89: 271-6. [CrossRef]

107. Asnaashari S, Delazar A, Alipour SS, Nahar L, Williams AS, Pasdaran A, et al. Chemical Composition, Free-Radical-Scavenging and Insecticidal Activities of The Aerial Parts of Stachys byzantina. Arch. Biol. Sci. 2010; 62: 653-62. [CrossRef]

108. Figueiredo AC, Barroso JG, Pedro LG, Salgueiro L, Miguel MG, Faleiro ML. Portuguese Thymbra and Thymus species volatiles: chemical composition and biological activities. Curr. Pharm. Des 2008; 14: 3120-40. [CrossRef] 
109. Costa P, Goncalves S, Grosso C, Andrade PB, Valentao P, Bernardo-Gil, MG, Romano A. Chemical profiling and biological screening of Thymus lotocephalus extracts obtained by supercritical fluid extraction and hydrodistillation Ind Crop Prod 2012; 36: 246-56.

110. Sekeroglu N, Deveci M, Buruk CK, Gurbuz B, Ipek A. Chemical composition and antimicrobial activity of Anzer tea essential oil. J. Sci. Food Agr 2007; 87: 1424-6. [CrossRef]

111. Tsai ML, Lin CC, Lin WC, Yang CH. Antimicrobial, Antioxidant, and Anti-Inflammatory Activities of Essential Oils from Five Selected Herbs. Biosci. Biotech. Bioch 2011; 75: 1977-83. [CrossRef]

112. Bakhtiarian A, Khanavi M, Moghaddam FA. Anti-inflammatory effect of Thymus kotschyanus extract on rat's hind paw edema induced by carrageenan. Toxicol. Lett 2011; 205: 235-6. [CrossRef]

113. Chen HP, Weisskopf MG, O’Reilly E, McCullough ML, Calle EE, et al. Pesticide exposure and risk for Parkinson's disease. Ann Neurol 2006; 60: 197-203. [CrossRef]

114. Kim SI, Jung JW, Ahn YJ, Restifo LL, Kwon HW. Drosophila as a model system for studying lifespan and neuroprotective activities of plant-derived compounds. J. Asia Pac. Entomol 2011; 14: 509-17. [CrossRef]

115. Savelev SU, Okello EJ, Perry EK. Butyryl- and acetylcholinesterase inhibitory activities in essential oils of Salvia species and their constituents. Phytother. Res 2004; 18: 315-24. [CrossRef] 